\title{
JIP1-Mediated JNK Activation Negatively Regulates Synaptic Plasticity and Spatial Memory
}

\author{
Caroline Morel, ${ }^{1,2 *}$ Tessi Sherrin, ${ }^{3 *}$ Norman J. Kennedy, ${ }^{1,2}$-Kelly H. Forest, ${ }^{3}$ Seda Avcioglu Barutcu, ${ }^{1,2}$ \\ ๑Michael Robles, ${ }^{3}$ Ezekiel Carpenter-Hyland, ${ }^{4}$ Naghum Alfulaij, ${ }^{3}$ Claire L. Standen, ${ }^{1,2}{ }^{-}$Robert A. Nichols, ${ }^{3}$

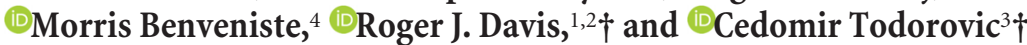 \\ ${ }^{1}$ Howard Hughes Medical Institute, ${ }^{2}$ Program in Molecular Medicine, University of Massachusetts Medical School, Worcester, Massachusetts 01605, \\ ${ }^{3}$ Department of Cell and Molecular Biology, John A. Burns School of Medicine, University of Hawaii, Honolulu, Hawaii 96813 , and ${ }^{4}$ Neuroscience Institute, \\ Morehouse School of Medicine, Atlanta, Georgia 30310
}

The c-Jun N-terminal kinase (JNK) signal transduction pathway is implicated in learning and memory. Here, we examined the role of JNK activation mediated by the JNK-interacting protein 1 (JIP1) scaffold protein. We compared male wild-type mice with a mouse model harboring a point mutation in the Jip1 gene that selectively blocks JIP1-mediated JNK activation. These male mutant mice exhibited increased NMDAR currents, increased NMDAR-mediated gene expression, and a lower threshold for induction of hippocampal long-term potentiation. The JIP1 mutant mice also displayed improved hippocampus-dependent spatial memory and enhanced associative fear conditioning. These results were confirmed using a second JIP1 mutant mouse model that suppresses JNK activity. Together, these observations establish that JIP1-mediated JNK activation contributes to the regulation of hippocampus-dependent, NMDAR-mediated synaptic plasticity and learning.

Key words: fear; JIP1; JNK; LTP; memory; plasticity

Significance Statement

The results of this study demonstrate that c-Jun N-terminal kinase (JNK) activation induced by the JNK-interacting protein 1 (JIP1) scaffold protein negatively regulates the threshold for induction of long-term synaptic plasticity through the NMDA-type glutamate receptor. This change in plasticity threshold influences learning. Indeed, mice with defects in JIP1-mediated JNK activation display enhanced memory in hippocampus-dependent tasks, such as contextual fear conditioning and Morris water maze, indicating that JIP1-JNK constrains spatial memory. This study identifies JIP1-mediated JNK activation as a novel molecular pathway that negatively regulates NMDAR-dependent synaptic plasticity and memory.

\section{Introduction}

Human genetic studies have demonstrated that mutations in genes underlying the cJun $\mathrm{NH}_{2}$-terminal kinase (JNK) signaling

Received July 7, 2017; revised Feb. 6, 2018; accepted March 3, 2018.

Author contributions: C.T., C.M., and T.S. wrote the first draft of the paper; N.K. and R.J.D. edited the paper. C.T. C.M., T.S., N.K., M.B., and R.J.D. designed research; C.T., C.M., T.S., N.K., M.R., E.C.-H., N.A., C.S., K.H.F., and S.A.B. performed research; C.T., C.M., T.S., N.K., R.A.N., M.B., and R.J.D. analyzed data; C.T., N.K., R.A.N., M.B., and R.J.D. wrote the paper.

This work supported by the National Institutes of Health (Grants U54MD008149 and MH086733 to C.T.; Grants S11NS055883, U54NS083932, and SC1AG046907 to M.B.; and Grant G12MD007601 to the behavior and electrophysiology core at the University of Hawaii). R.J.D. is an investigator at the Howard Hughes Medical Institute. We thank Tamera Barrett for technical assistance and Kathy Gemme for administrative assistance.

The authors declare no competing financial interests.

${ }^{*}$ C.M. and T.S. contributed equally to this work.

TR.J.D. and C.T. contributed equally to this work.

Correspondence should be addressed to either of the following: Cedomir Todorovic, Department of Cell and Molecular Biology, John A Burns School of Medicine, University of Hawaii, 631 llalo St., Honolulu, HI 96813, E-mail: cedomir@hawaii.edu; or Roger J. Davis, Howard Hughes Medical Institute and Program in Molecular Medicine, University of Massachusetts Medical School, 373 Plantation Street, Worcester, MA 01605, E-mail: roger.davis@umassmed.edu. pathway are associated with neuropsychiatric, neurological, and neurodevelopmental disorders, including schizophrenia (MAP2K7; Winchester et al., 2012), epilepsy (MAPK10; Shoichet et al., 2006), autism spectrum disorder (MAPK8IP2 and TAOK2; Weiss et al., 2008; Giza et al., 2010; de Anda et al., 2012), and learning disability (MAPK10; Baptista et al., 2008; Kunde et al., 2013). These observations suggest that the JNK pathway has an important normal function in the CNS. Indeed, recent studies using $C$. elegans (Inoue et al., 2013) and murine (Sherrin et al., 2011) experimental models showed that JNK deficiency results in enhanced memory. This is exemplified by the observations that JNK1-deficient mice exhibit enhanced associative learning, including contextual fear conditioning (Sherrin et al., 2010) and altered synaptic plasticity (Li et al., 2007). Complementary studies using pharmacological inhibition of JNK demonstrate increased long-term depression (LTD) and loss of depotentiation 
(Yang et al., 2011). Moreover, JNK activation has been implicated in stress-mediated inhibition of long-term potentiation (LTP; Curran et al., 2003; Wang et al., 2004). Mechanisms that contribute to JNK-regulated synaptic plasticity include NMDARstimulated JNK activation (Mukherjee et al., 1999), AMPAR internalization (Zhu et al., 2005), and synaptic recruitment of PSD95 (Kim et al., 2007). Collectively, these data indicate that JNK plays a key role in the regulation of synaptic plasticity.

Although progress toward understanding the role of JNK in neuronal signaling has been achieved, little is known about the mechanisms that regulate JNK during behavioral responses. Previous studies have implicated roles for scaffold proteins in the control of MAP kinase (MAPK) signaling cascades, including the JNK signaling pathway (Morrison and Davis, 2003). Indeed, the JNK-interacting protein 1 (JIP1) scaffold protein can assemble a functional JNK signaling pathway (Whitmarsh et al., 1998, 2001). JIP1 is required for JNK activation caused by specific stimuli, including metabolic and excitotoxic stress (Whitmarsh et al., 2001; Morel et al., 2010). However, JIP1 is not required for JNK activation caused by other stimuli, including inflammatory cytokines (Whitmarsh et al., 2001).

JIP1 is highly expressed in the brain (Dickens et al., 1997; Whitmarsh et al., 1998) and localizes to synapses (Pellet et al., 2000). Interestingly, mice with JIP1 deficiency exhibit increased NMDAR signaling (Kennedy et al., 2007), implicating JIP1-mediated JNK activation in the regulation of NMDAR activity. The purpose of this study was to examine the impact of JIP1-regulated JNK activation on neuronal function and behavior. JIP1 may contribute to multiple biological processes, including microtubule motor protein function and JNK signaling (Morrison and Davis, 2003). The interpretation of studies using JIP1 knock-out mice (Whitmarsh et al., 2001) is therefore complicated by the presence of defects in JIP1-mediated JNK activation and defects in other JIP1-mediated biochemical activities. Therefore, we examined the effect of a point mutation in JIP1 ( $\left.\mathrm{Thr}^{103} \mathrm{Ala}\right)$ that selectively prevents JIP1-mediated JNK activation (Morel et al., 2010). This block in JNK activation is accounted for by a required role of JIP1 phosphorylation on $\mathrm{Thr}^{103}$ for dynamic association with upstream MAP3K components of the signaling cascade (Nihalani et al., 2003; Morel et al., 2010). Our results demonstrated that JIP1mediated JNK activation regulates hippocampus-dependent, NMDAR-linked synaptic plasticity and memory. This conclusion was confirmed using a second mouse model with point mutations that disrupt the JNK-binding site on JIP1, which also prevents JIP1-mediated JNK activation and alters hippocampusdependent learning. Collectively, the data demonstrate that the JIP1-JNK signaling axis negatively regulates synaptic plasticity and spatial memory, possibly functioning to constrain and/or shape learning and memory under specific contexts.

\section{Materials and Methods}

Mice. C57BL/6J mice (stock number 000664) were obtained from The Jackson Laboratory and were established as a colony in our facility. The Jip1 Thr ${ }^{103}$ Ala $\left(J I P 1^{\mathrm{TA}}\right.$ ) mice have been described previously (Morel et al., 2010). Mice with a defect in the JNK-binding domain (JBD) of JIP1 (replacement of Leu ${ }^{160}$-Asn ${ }^{161}$-Leu ${ }^{162}$ with Gly ${ }^{160}$-Arg ${ }^{161}$-Gly ${ }^{162}$ ) were established by homologous recombination in embryonic stem (ES) cells using standard methods. The mutated allele is designated as Jip1 ${ }^{\Delta \mathrm{JBD}}$. Briefly, a targeting vector was constructed that was designed to introduce point mutations in exon 3 of the Jipl gene to create the $\Delta$ JBD mutation. TC1 ES cells (strain129svev; RRID:CVCL_M350) were electroporated with this vector and selected with $200 \mu \mathrm{g} / \mathrm{ml}$ G418 (Thermo Fisher Scientific, catalog \#10131035) and $2 \mu \mathrm{M}$ ganciclovir (Millipore, catalog $\# 345700$ ). ES cell clones without (genotype $+/$ NeoR-Jip1 $^{\mathrm{WT}}$ ) and with (genotype $+/$ NeoR-Jip1 ${ }^{\Delta \mathrm{JBD}}$ ) the $\Delta \mathrm{JBD}$ mutation in exon 3 were identified. These ES cells were injected into C57BL/6J blastocysts to create chimeric mice that were bred to obtain germline transmission of the targeted Jip1 allele. The floxed $\mathrm{NeO}^{\mathrm{R}}$ cassette was excised using Cre recombinase. The full characterization of these mice has been described previously (Kant et al., 2017). All mice used in this study were backcrossed (10 generations) to the C57BL/6J strain (The Jackson Laboratory). All studies were performed using male mice. The mice were housed in a facility accredited by the American Association for Laboratory Animal Care. The Institutional Animal Care and Use Committee of the University of Massachusetts, University of Hawaii, and Morehouse School of Medicine approved all studies using animals.

Primary hippocampal neurons. Embryonic day 16.5 mouse embryos were used for isolation of primary hippocampal neurons (Whitmarsh et al., 2001). Briefly, hippocampi were placed in ice-cold Hank's buffered saline solution containing 20 mM HEPES (pH 7.3; HBSS, Thermo Fisher Scientific, catalog \#15630080) and digested with $1 \%$ trypsin (Thermo Fisher Scientific, catalog \#17075029) in the presence of $1 \mathrm{mg} / \mathrm{ml}$ DNase I (Sigma-Aldrich, catalog \#11284932001). The trypsin solution was removed and the minced tissue was triturated in $1.0 \mathrm{ml}$ of HBSS- $20 \mathrm{~mm}$ HEPES containing DNase I (1 mg/ml; Sigma-Aldrich, catalog \#11284932001) and soybean trypsin inhibitor $(0.5 \mathrm{mg} / \mathrm{ml}$; Thermo Fisher Scientific, catalog \#17075029) to obtain a single-cell suspension. Dissociated neurons were centrifuged $\left(180 \times g, 10 \mathrm{~min}, 4^{\circ} \mathrm{C}\right)$ through a cushion of $4 \%$ bovine serum albumin (BSA; Thermo Fisher Scientific, catalog \#B14) in HBSS. Hippocampal neurons were seeded in poly-D-lysine/laminin-coated chamber slides (BD Biosciences, catalog \#354687) in Neurobasal medium (Thermo Fisher Scientific, catalog \#21103049) containing B27 supplement (Thermo Fisher Scientific, catalog \#17504044), 1\% glutamine (Thermo Fisher Scientific, catalog \#21051024), and 1\% penicillin/streptomycin (Thermo Fisher Scientific, catalog \#15140122).

Gene expression studies were performed using hippocampal neurons cultured for $14 \mathrm{~d}$ in vitro (DIV). The neurons were treated without or with $100 \mu \mathrm{M}$ NMDA/10 $\mu \mathrm{M}$ Glycine (Sigma-Aldrich, catalog \#M3262, catalog \#G5417) in complete Neurobasal media (Thermo Fisher Scientific, catalog \#21103049). The expression of mRNA was measured by quantitative RT-PCR assays.

Immunofluorescence analysis was performed using hippocampal neurons cultured for $16 \mathrm{~d}$ in vitro (16 DIV). Two different procedures were used to prepare neurons for immunofluorescence analysis. First, permeabilized fixed neurons were prepared by incubation with $4 \%(\mathrm{w} / \mathrm{v})$ paraformaldehyde (Thermo Fisher Scientific, catalog \#28906) at room temperature $(20 \mathrm{~min})$, followed by incubation with $0.1 \%$ Triton X-100 in PBS (5 min; Thermo Fisher Scientific, catalog \#85112) and then blocking buffer (1\% BSA (Thermo Fisher Scientific, catalog \#B14)), 2\% normal goat serum (Thermo Fisher Scientific, catalog \#31872) in PBS for $1 \mathrm{~h}$. Second, nonpermeabilized fixed neurons were prepared by incubation with $4 \%(\mathrm{w} / \mathrm{v})$ paraformaldehyde/4\% (w/v) sucrose (Thermo Fisher Scientific, catalog \#28906; Fisher Scientific, catalog \#BP-2201) at room temperature $(8 \mathrm{~min})$, followed by incubation $(1 \mathrm{~h})$ in blocking buffer. Neurons prepared by both methods were incubated overnight with primary antibodies to GluN1 (1:100, Millipore, catalog \#05-432, RRID: AB_390129) and $\beta$-Tubulin (1:500), Covance Research Products, catalog \#PRB-433C-200, RRID:AB_291636) in blocking buffer and then washed. The primary antibodies were detected by incubation with antimouse or anti-rabbit Ig conjugated to Alexa Fluor 488 or 633 (1:200, Invitrogen, catalog \#A-11094, RRID:AB_221544; Thermo Fisher Scientific, catalog \#A21100, RRID:AB_10374307). DNA was detected by staining with DAPI (Vectashield with DAPI, Vector Laboratories, catalog \#H-1200). Fluorescence was visualized using a Leica TCS SP2 confocal microscope equipped with a $405 \mathrm{~nm}$ diode laser. The mean fluorescence intensity was quantitated using ImageJ software (RRID:SCR_001775).

Preparation of synaptosomes. Hippocampi from 4 mice (age 8-12 weeks) were isolated and homogenized in Syn-PER buffer (Thermo Fisher Scientific, catalog \#87793). Briefly, neuronal tissue was homogenized in Syn-PER reagent, centrifuged following manufacturer's instructions, and the resulting synaptosome pellet was suspended in Syn-PER reagent to yield 3-4 $\mu \mathrm{g} / \mu \mathrm{l}$ of synaptic protein. The synaptosomes contain the complete presynaptic terminal, including mitochondria and syn- 
aptic vesicles, and also the postsynaptic membrane and the postsynaptic density (Villasana et al., 2006).

RNA analysis. The expression of mRNA was examined by qRT-PCR analysis using a 7500 Fast real-time PCR machine. TaqMan assays were used to quantitate cFos (Mm00487425_m1), cJun (Mm00495062_s1), Bdnf (Mm00432069_m1), GluN1 (Grin1, Mm00433800_m1), GluN2A (Grin2a, Mm00433802_m1), and GluN2B (Grin2b, Mm00433820_m1; Thermo Fisher Scientific). The relative mRNA expression was normalized by measurement of Gapdh (4352339E-0904021; Thermo Fisher Scientific) in each sample using TaqMan assays.

Immunoblot analysis. Tissue extracts were prepared from snap-frozen brain regions from adult mice ( $8-12$ weeks old) using Triton X-100 lysis buffer (20 mm Tris-pH 7.4, 1\% Triton X-100, 10\% glycerol, $137 \mathrm{~mm}$ $\mathrm{NaCl}, 2$ mm EDTA, 25 mm b-glycerophosphate, 1 mm sodium orthovanadate, $1 \mathrm{~mm}$ PMSF, $10 \mathrm{mg} / \mathrm{ml}$ Leupeptin, and $10 \mathrm{mg} / \mathrm{ml}$ Aprotinin). Extracts $(20-50 \mu \mathrm{g}$ of protein) were examined by protein immunoblot analysis by probing with antibodies to $\mathrm{pSer}^{63}$-cJun $(1: 1000$, Cell Signaling Technologies, catalog \#2361, RRID:AB_490908), JNK (1:1000, Cell Signaling Technologies, catalog \#9252, RRID:AB_2250373), GAPDH (Cell Signaling Technologies, catalog \#2118, RRID:AB_561053), GluN2B (1:1000, Cell Signaling Technologies, catalog \#4212S, RRID:AB_2112463), SAP102 (1:1000, Cell Signaling Technologies, catalog \#3730S, RRID: AB_2092180), pERK1/2 (1:1000, Cell Signaling Technologies, catalog \#5683P, RRID:AB_10841299), pSer ${ }^{133}$ CREB (1:1000, Cell Signaling Technologies, catalog \#9198, RRID:AB_2561044) and CREB (1:1000, Cell Signaling Technologies, catalog \#9197, RRID:AB_321277), ERK2 (1:1000, Santa Cruz Biotechnology, catalog \#sc-81457, RRID: AB_1122619), JNK1/2 (Santa Cruz Biotechnology, catalog \#sc-137019, RRID:AB_2140722), pJNK (Santa Cruz Biotechnology, catalog \#sc-6254, RRID:AB_628232) and GluN2A (1:500, Millipore, catalog \#07-632, RRID: AB_310837), $\mathrm{pY}^{1472}$ GluN2B (1:1000, Millipore, catalog \#AB5403, RRID: AB_11210694); GluN1 (Millipore, catalog \#05-432, RRID:AB390129), GluA1 (1:2000, Millipore, catalog \#04-855, RRID:AB_1977216), GluA2 (1:1000, Millipore, catalog \#07-261, RRID:AB_2116167), Synapsin I (1:1000, Millipore, catalog \#AB 1543, RRID:AB_11210367), $\beta$-Tubulin (1:5000, Covance Research Products, catalog \#PRB-435P-100, RRID:AB_291637), PSD-95 (1:2000, Sigma-Aldrich, catalog \#P246, RRID:AB_260911) and KIF17 (1:1000, Sigma-Aldrich, catalog \#K3638, RRID:AB_477148). Immunocomplexes were detected by fluorescence using anti-mouse (1:5000, LI-COR Biosciences, catalog \#926-32210, RRID:AB_621842) and anti-rabbit secondary IRDye antibodies (1:5000, LI-COR Biosciences, catalog \#827-08365, RRID:10796098) and quantitated using a LI-COR imaging system.

Multiplexed ELISA. Quantitative analysis of $\mathrm{pSer}^{63}$-cJun (Bio-Rad, catalog \#171-V50003M), cJun (Bio-Rad, catalog \#171-V60002M), pJNK (BioRad, catalog \#171-V50011M), JNK (Bio-Rad, catalog \#171-V60007M), pERK (Bio-Rad, catalog \#171-V50006M), and ERK1/2 (Bio-Rad, catalog \#171-V60003M) was performed using Bio-Plex Pro Cell Signaling Reagent kit (Bio-Rad, catalog \#171-304006M) and a Luminex 200 instrument (Millipore-Sigma-Aldrich).

Kainate-induced excitotoxicity. JIP1 ${ }^{\mathrm{WT}}$ and JIP $1^{\mathrm{TA}}$ mice $(8-12$ weeks old) were injected intraperitoneally with $30 \mathrm{mg} / \mathrm{kg}$ kainic acid (Tocris Bioscience, catalog \#0222; Yang et al., 1997). At $2 \mathrm{~h}$ posttreatment, the mice were perfused with $4 \%$ paraformaldehyde. Brains were harvested and fixed for an additional $24 \mathrm{~h}$ in $4 \%$ paraformaldehyde and then dehydrated and embedded in paraffin. Coronal sections $(5 \mu \mathrm{m})$ were cut, rehydrated, and subjected to heat-induced antigen retrieval (Vector Laboratories, catalog $\# \mathrm{H}-3301)$. Sections were blocked for $1 \mathrm{~h}$ at room temperature (1\% BSA, 2\% normal goat serum, $0.4 \%$ Triton X-100 in PBS) and incubated overnight with primary antibodies to pSer ${ }^{63}$-cJun (1:100, Cell Signaling Technologies, catalog \#2361, RRID:AB_490908), or cFos (1: 200, Cell Signaling Technologies, catalog \#4384S, RRID:AB_10698737) or cJun (1:100, Santa Cruz Biotechnology, catalog \#sc-1694, RRID: AB_631263). The primary antibodies were detected by incubation with anti-rabbit Ig conjugated to Alexa Fluor 488 (1:200, Thermo Fisher Scientific, catalog \#A11008, RRID:AB_143165). DNA was detected by staining with DAPI (Vectashield with DAPI, Vector Laboratories, catalog $\#$ H-1200). Fluorescence was visualized using a Leica TCS SP2 confocal microscope equipped with a $405 \mathrm{~nm}$ diode laser.
Surgery and infusions. Mice were anesthetized with $1.2 \%$ Avertin $(25 \mathrm{~g}$ 2, 2, 2-Tribromoethanol, Sigma-Aldrich, catalog \#T4, 840-2, $15.5 \mathrm{ml}$ of tert-amyl alcohol (2-methyl-2-butanol), Fisher Scientific, catalog \#A730-1) and implanted bilaterally with 26 gauge guide cannulae (Plastics One) into the dorsal hippocampus (AP $-1.5 \mathrm{~mm}$, lateral $1 \mathrm{~mm}$, depth $1.3 \mathrm{~mm}$ ). Mice were allowed to recover for at least $7 \mathrm{~d}$ before behavioral experiments. Intrahippocampal infusions were made using custom 28 gauge injectors (Plastics One, catalog \#C232I/SPC) that extended $1 \mathrm{~mm}$ beyond the tips of the guide cannulae. On the day of the experiment, bilateral injections were performed using an infusion pump (CMA/100; CMA/Microdialysis) at a constant rate of $0.5 \mu \mathrm{l} / \mathrm{min}$ (final volume: 0.25 $\mu \mathrm{l} /$ side). The competitive NMDAR antagonist D,L-2-amino-5-phosphonovaleric acid (APV; $10 \mu \mathrm{g} / \mathrm{ml}$; Sigma-Aldrich, catalog \#A5282) was dissolved in aCSF (aCSF) containing the following (in mM): $130 \mathrm{NaCl}, 3.5$ $\mathrm{KCl}, 10$ glucose, $1.25 \mathrm{NaH}_{2} \mathrm{PO}_{4}, 2.0 \mathrm{CaCl}_{2}, 1.5 \mathrm{MgSO}_{4}$, and $24 \mathrm{NaHCO}_{3}$. Controls received equal volumes of aCSF infused at the same rate. All infusions were made 15 min before contextual fear conditioning.

Analysis of dendritic spine density and morphology. Golgi staining was performed using the FD Rapid Golgi Stain Kit (FD Neurotechnologies, catalog \#PK401) following the manufacturer's guidelines. Coronal sections $(150 \mu \mathrm{m})$ were obtained using a microtome (Leica VT1000S). Spines examined were apical (stratum radiatum) and basal (stratum oriens) dendrites of CA1 pyramidal neurons. CA1 pyramidal neurons were traced using a Zeiss Axioskop 2 Plus microscope with a $100 \times$ oil-immersion objective. Only pyramidal neurons that exhibited complete impregnation and not obscured by other neurons or artifacts were examined. Five neurons per animal were 3D reconstructed using NeuroLucida Software (MicroBrightField; RRID:SCR_001775). At least three apical ( $>50 \mu \mathrm{m}$ from soma) and three basal ( $>30 \mu \mathrm{m}$ from soma) dendritic segments $(>25$ $\mu \mathrm{m}$ length) were quantified in each neuron. Spine densities were calculated as mean numbers of spines per $10 \mu \mathrm{m}$ per dendrite per neuron in individual mice. Dendritic arborization was performed using Sholl analysis of the apical and basilar dendrites of these neurons. Briefly, a series of increasingly large concentric circles centered at the cell body and separated by $10-\mu \mathrm{m}$-radius intervals were superimposed upon traces of apical and basilar dendrites; the number of dendritic intersections with each concentric circle was recorded. On the basis of morphology, spines were classified into the following categories: thin, mushroom, and stubby (Korobova and Svitkina, 2010).

Analysis of tissue sections. Paraformaldehyde-fixed brains were cryoprotected in $30 \%$ sucrose in $0.1 \mathrm{M} \mathrm{PBS}$ for $48 \mathrm{~h}$ at $4^{\circ} \mathrm{C}$. Immunohistochemical analysis was performed on free-floating sections cut at $30 \mu \mathrm{m}$ on a cryostat. The sections were washed once with PBS and blocked with $5 \%$ goat serum (Vector Laboratories, catalog \#S-1000) in PBST (PBS + $0.3 \%$ Triton $\mathrm{X}-100)$ for $1 \mathrm{~h}$. The sections were then incubated overnight with primary antibodies to JIP1 (1:500, BD Biosciences, catalog \#611890, RRID:AB_399370), anti-NeuN antibody (1:500, Millipore, catalog \#MAB377, RRID:AB_2298772), MAP2 antibody (1: 500, Millipore, catalog \#AB5622, RRID:AB_91939), GAD67 antibody (1: 5000, Millipore, catalog \#MAB5406, RRID:AB_2278725), or GFAP antibody (1:150, Promega, catalog \#G5601, RRID:AB_430855) at $4^{\circ} \mathrm{C}$. The sections were washed in PBST and incubated $(1 \mathrm{~h})$ with anti-mouse Ig or anti-rabbit Ig conjugated to Alexa Fluor 488 (Thermo Fisher Scientific, catalog \#S11223, RRID:AB_2336881) or Alexa Fluor 546 (Thermo Fisher Scientific, catalog \#S11225, RRID:AB_2532130). Nuclei were stained using DAPI (Vectashield with DAPI, Vector Laboratories, catalog \#H1200). Images were obtained with a Zeiss Axio Imager 2 microscope at $10 \times$ and $20 \times$ magnification. The mean fluorescence intensity was quantitated using ImageJ (RRID:SCR_003070) software. Sections were also examined using Nissl stain (Thermo Fisher Scientific, cata$\log \#$ N21479).

Fear conditioning and extinction. Context-dependent and tone-dependent fear conditioning were performed using a computer-controlled fear conditioning system (TSE Systems; Todorovic et al., 2007). The fear-conditioning experiment was performed in a Plexiglas cage $(36 \times 21 \times 20 \mathrm{~cm})$ within a fear-conditioning box. The training (conditioning) consisted of a single trial. The mouse was exposed to the conditioning context (180 s), followed by a tone [conditioned stimulus (CS), $30 \mathrm{~s}, 10 \mathrm{kHz}, 75 \mathrm{~dB}$ SPL, pulsed $5 \mathrm{~Hz}$ ]. After termination of the tone, a foot shock [unconditioned 
A

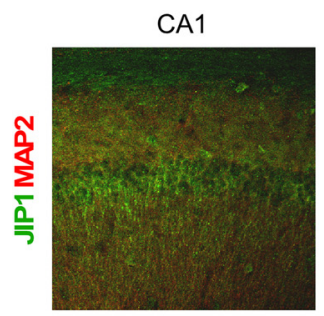

CA1

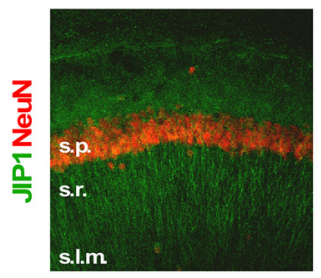

CA3



CA3

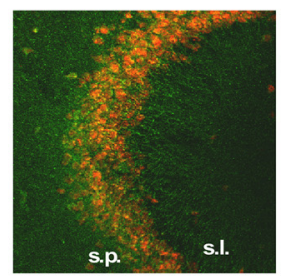

DG

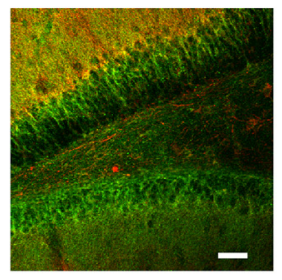

DG

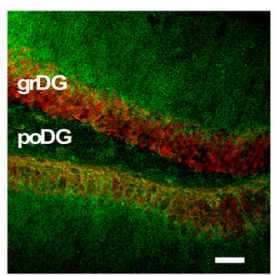

B



D

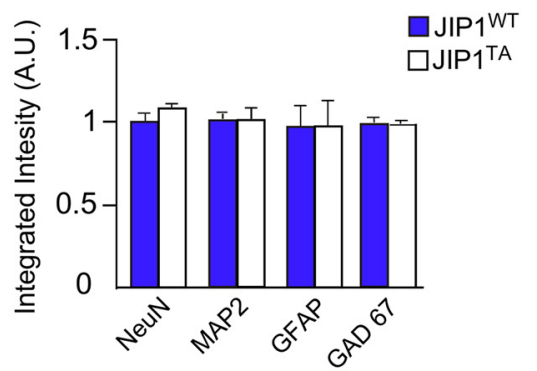

JIP1 $1^{\top A}$

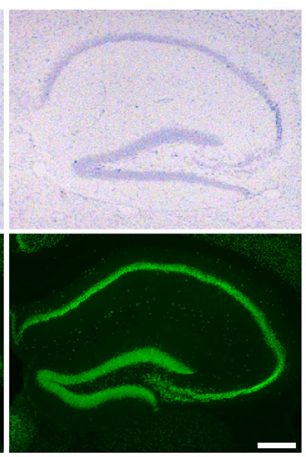

C
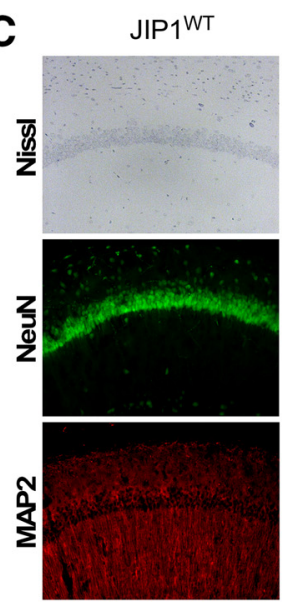

$\mathrm{JIP} 1^{\top \mathrm{A}}$
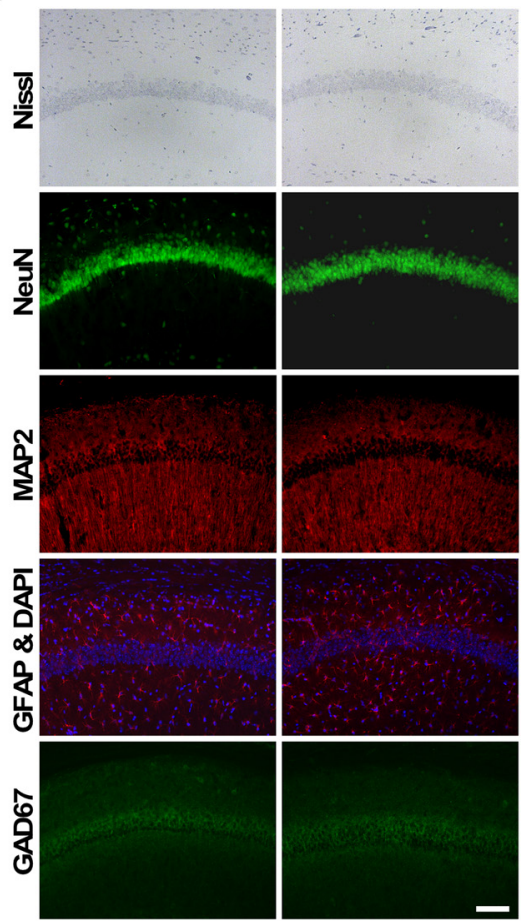

Figure 1. Analysis of JIP1 expression in the hippocampus. A, Fluorescent immunohistochemistry of the CA1, CA3, and DG regions of the hippocampus indicates that JIP1 (green) predominantly colocalizes with MAP2 (red) in wild-type brain sections (top), suggesting relative enrichment of the JP1 protein in neuronal processes. Colocalization between JIP1 (green) and neuron-specific nuclear protein (NeuN; red) is sparse in the hippocampal subfields (bottom). CA1, Cornu ammonis 1; CA3, cornu ammonis 3; grDG, granular layer of DG; poDG, polymorphic layer of DG; s.l., stratum lucidem; s.I.m., stratum lacunosum moleculare; s.p., stratum pyramidale; s.r., stratum radiatum. Scale bar, $50 \mu \mathrm{m}$. B, Nissl stain and NeuN stain of JIP1 ${ }^{\mathrm{WT}}$ and JIP1 ${ }^{\mathrm{TA}}$ coronal hippocampal sections. Scale bar, $200 \mu \mathrm{m}$. C, D, Pyramidal cells of the CA1 region of JPP1 ${ }^{\mathrm{WT}}$ and JIP1 ${ }^{\mathrm{TA}}$ were stained with Nissl, NeuN, the dendritic marker MAP2, the astrocytic marker GFAP, and the inhibitory GABAergic marker GAD67 (C). The staining was quantitated (D) (mean \pm SEM; $n=4 ; p>0.05 ;$ Student's $t$ test). Scale bar, $50 \mu \mathrm{m}$.

stimulus (US), $0.8 \mathrm{~mA}$ or $0.4 \mathrm{~mA}, 2 \mathrm{~s}$, constant current] was delivered through a stainless steel grid floor. Under these conditions, the context served as background stimulus. Background contextual fear conditioning, but not foreground contextual fear conditioning, in which the tone is omitted during training, has been shown to involve the hippocampus (Phillips and LeDoux, 1992). A loudspeaker provided constant background noise. Contextual memory was tested in the fear-conditioning box for $180 \mathrm{~s}$ without CS or US presentation (with background noise) $24 \mathrm{~h}$ after contextual fear conditioning. The context-dependent extinction trials were performed at $24 \mathrm{~h}$ intervals and consisted of nonreinforced 3 min exposures (absence of a foot shock) to the same context. For fear response extinction, the aforementioned protocol was used to acquire contextual fear memory. Tone-dependent memory test was per- formed in a novel context (context 2) $24 \mathrm{~h}$ after cued fear conditioning. Context 2 represented an identically sized cage with a plain floor in a light-surrounding environment (350-500 lux) outside the fear-conditioning box. No background noise was provided in context 2. During tone-dependent memory test, a 180 s pause without stimulation (pre-CS phase) preceded a $180 \mathrm{~s}$ period of auditory stimulation. Freezing, defined as a lack of movement except for respiration, was recorded every $10 \mathrm{~s}$ by a trained observer for a total of 18 sampling intervals. The mean number of observations indicating freezing was expressed as a percentage of the total number of observations. The exploration of the fear-conditioning box during the training and activity burst produced by electric foot shock were automatically detected by an infrared beam system and analyzed using TSE Systems software. 
Morris water maze (MWM). The MWM paradigm (Morris et al., 1982) was performed in a circular tank (diameter $180 \mathrm{~cm}$; height $75 \mathrm{~cm}$ ) located in a room with various distal cues. The tank was filled with water ( $40 \mathrm{~cm}$ depth) maintained at $23^{\circ} \mathrm{C}$, which was made opaque by the addition of a nontoxic white paint. Inside the pool was a removable, circular $(12 \mathrm{~cm}$ in diameter) Plexiglas platform $0.5 \mathrm{~cm}$ below the surface of the water. On the first $2 \mathrm{~d}$, each mouse received visible platform training that consisted of 4 consecutive trials of climbing onto the visible platform (with a black plastic brick placed above it) until each subject was able to climb without help. For the hidden platform task, the mice were given four consecutive trials per day starting from four different pseudorandomized start locations with a $15 \mathrm{~min}$ intertrial interval. Mice were allowed to search for the hidden platform for $60 \mathrm{~s}$. If the mice did not find the platform within $60 \mathrm{~s}$, they were guided to it. Mice were allowed to rest on the platform for $15 \mathrm{~s}$ after each trial. The hidden platform task was composed of two phases: (1) $10 \mathrm{~d}$ (acquisition phase days 3-13) with a hidden platform located in the center of the target quadrant and (2) reversal phase (day 14) with a hidden platform located in the center of the quadrant opposite to the original target quadrant. Reversal platform training was conducted without changing any distal visual cues. Probe trials in which the escape platform was removed from the pool were conducted on days 10 (target quadrant), 13 (target quadrant), and 15 (opposite quadrant). During the memory test (probe trials), the platform was removed from the tank and the mice were allowed to swim in the maze for $60 \mathrm{~s}$. The swimming path of the mice was recorded by a video camera and analyzed with the computer-based tracking software Videomot 2 (TSE Systems, RRID: SCR_014334). The percentage of swim distance spent in the platform quadrant and the latency to find the platform were analyzed.

Rotarod test. Motor coordination and skill learning were assessed using an accelerating Rotarod (Stoelting). Starting speed for the Rotarod began at $4 \mathrm{rpm}$ and increased to $40 \mathrm{rpm}$ over a 5 min period. Mice were tested 4 times daily for 2 consecutive days with an intertrial interval of $1 \mathrm{~h}$ between tests. The latency to fall off the rod was measured for each trial.

Elevated plus maze test. The elevated plus maze test for anxiety-related behaviors was performed as described previously (Todorovic et al., 2007). Briefly, mice were placed in the center platform of the elevated plus maze and allowed to explore for $5 \mathrm{~min}$. Animal behavior was recorded by a video camera connected to a PC and analyzed by videotracking software (VideoMot 2, TSE Systems, RRID:SCR_014334). The percentage of time spent in the open and closed arms were recorded. Shift of preference from the open to the closed arms was interpreted as an increase of anxiety-like behavior. Locomotor activity was determined with this test by the distance traveled.

Open-field test. General exploratory activity and anxiety were assessed in an open-field test. Mice were placed in the center of an open-field apparatus $(50 \times 50 \mathrm{~cm})$ protected with $10-\mathrm{cm}$-high opaque walls and allowed to explore for $5 \mathrm{~min}$. The field was divided into 16 equal squares $(12.5 \times 12.5 \mathrm{~cm})$ consisting of 12 outer squares and four inner squares. Animal behavior was recorded by a video camera connected to a PC and analyzed by video-tracking software (VideoMot 2, TSE Systems, RRID: SCR_014334). The amount of time spent in the inner and outer squares and the total distance traveled was measured.
Basal dendrites
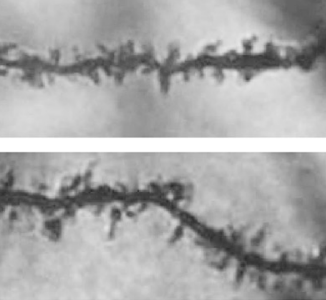

B Spine Density

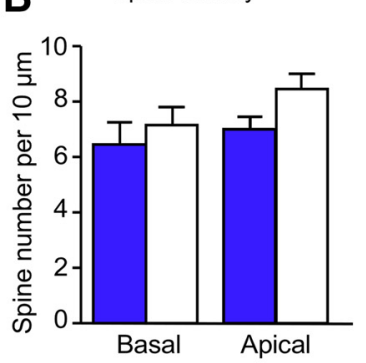

$\square \mathrm{JIP} 1^{\mathrm{WT}}$ $\square \mathrm{JIP1} 1^{\top \mathrm{A}}$



D Basal dendrites
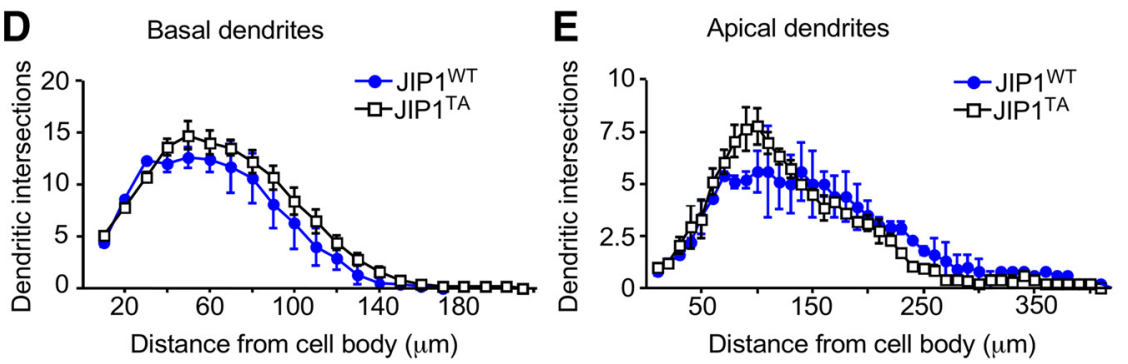

Apical dendrites

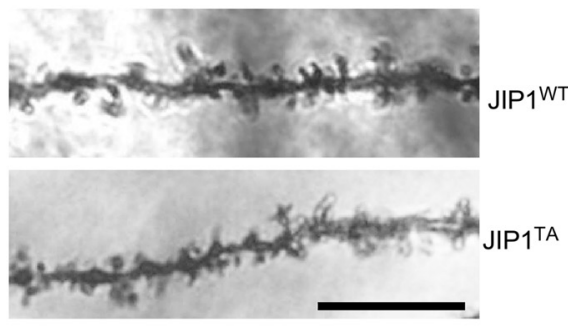

C

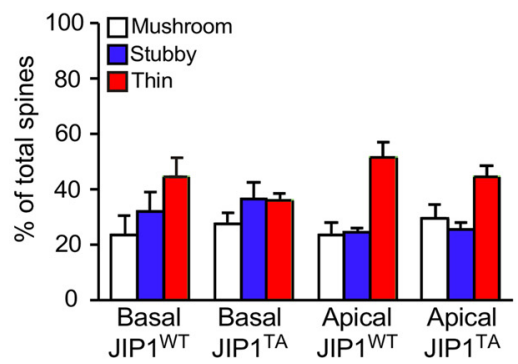

Spine Type

Figure 2. Neuronal spine density and dendritic arborization of CA1 pyramidal neurons are similar in JIP1 ${ }^{\mathrm{WT}}$ and JIP1 ${ }^{\mathrm{TA}}$ mice. (men \pm SEM; $n=5$ slices from 5 mice per genotype; $p>0.05$ represent increasing distance from the soma of the pyramidal cells. Basal and apical dendrites of pyramidal cells from $n=5$ slices from 5 mice per genotype were examined (mean \pm SEM; $p>0.05$, Student's $t$ test).

Acoustic startle and prepulse inhibition (PPI). Acoustic startle and PPI test were performed as described previously (Pitts et al., 2012). Mice were placed in the startle chamber (Responder-X; Columbus Instruments) and allowed a 5 min acclimation period with the background noise (70 $\mathrm{dB})$ continuously present. After the acclimation period, two blocks of trials were administered to assess the acoustic startle response and PPI, respectively. The first block of trials consisted of eight sets of four types of trials that were distributed randomly. Startle stimuli $(40 \mathrm{~ms})$ of varying intensities were administered, with an interstimulus interval of $15 \mathrm{~s}$. The stimulus intensities were $80,90,100$, and $110 \mathrm{~dB}$. Baseline activity was assessed by a set of no-stimulus trials. The startle amplitude was defined as the peak response during a $100 \mathrm{~ms}$ sampling window beginning with the onset of the startle stimulus. Mean startle amplitudes were derived by subtracting the average startle amplitudes of stimulus intensities used $(80-110 \mathrm{~dB})$ from the no-stimulus trial $(70 \mathrm{~dB})$. The second block of trials consisted of eight sets of five trial types, distributed randomly and separated by $20 \mathrm{~s}$ interstimulus intervals. The trial types were as follows: (1) no-stimulus/background noise (70 dB); (2) $40 \mathrm{~ms}, 110 \mathrm{~dB}$ startle alone; and (3-5) $110 \mathrm{~dB}$ startle preceded $100 \mathrm{~ms}$ by one of three $20 \mathrm{~ms}$ prepulses at the following intensities: 74,80 , or $86 \mathrm{~dB}$. The startle amplitude for each subject at each of the different prepulse intensities was calculated using the following formula: PPI $=100-100 \times$ (response amplitude for prepulse stimulus paired with startle stimulus/response amplitude for startle stimulus alone). 
A

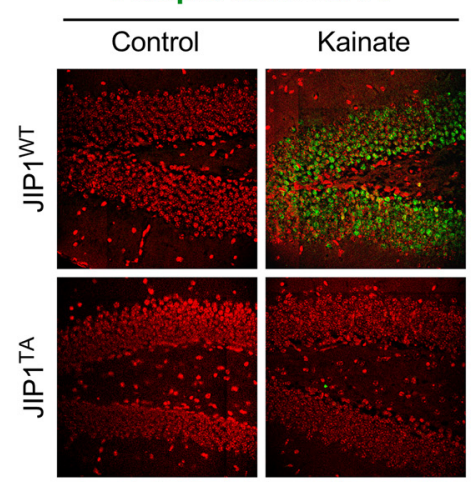

D

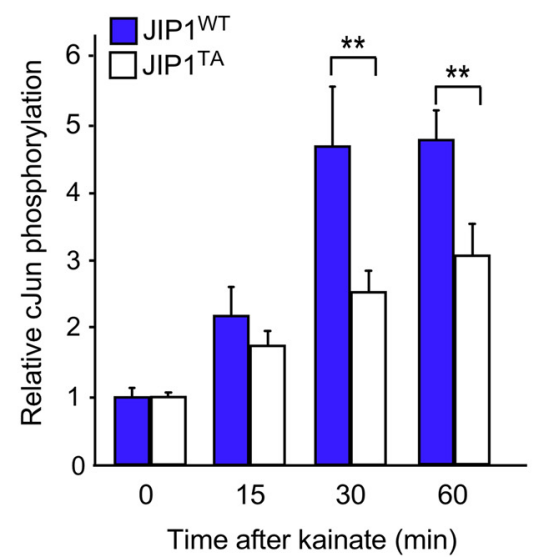

B

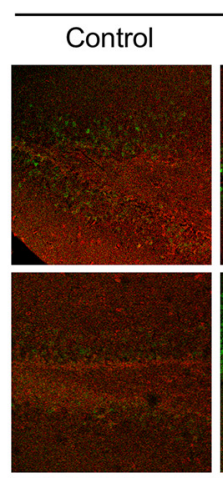

C



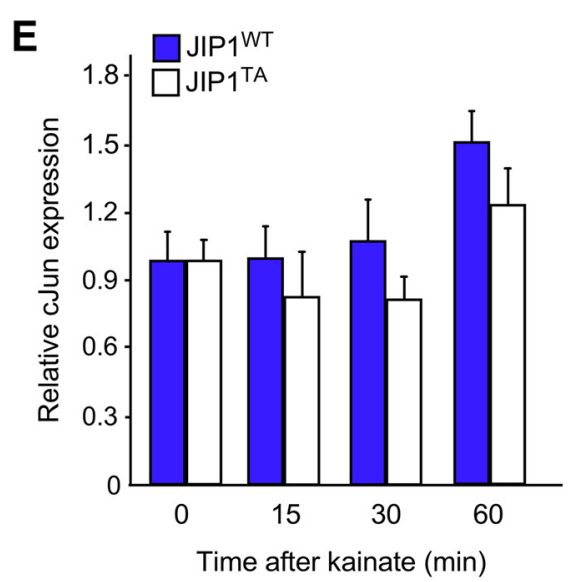

Figure 3. JIP1-dependent JNK activation in the hippocampus is suppressed in $J \mathbb{P} 1^{T A}$ mice. $A-C, J P 1^{W T}$ and $J I P 1^{T A}$ mice were treated by systemic injection of kainate. At $2 \mathrm{~h}$ after treatment, sections of the brain were prepared and stained (green) with antibodies to $\mathrm{pSer}{ }^{63}$ Jun $(\boldsymbol{A})$, clun $(\boldsymbol{B})$, or CFos (C). DNA was stained with DAPI (red). Representative sections of the DG of the hippocampus are presented. Scale bar, $75 \mu \mathrm{m} . \boldsymbol{D}, \boldsymbol{E}$, Extracts prepared from the hippocampus of JIP1 ${ }^{\mathrm{WT}}$ and JIP1 ${ }^{\mathrm{TA}}$ mice treated with kainate $(0-60$ min) were examined by multiplexed ELISA to measure the amount of $\mathrm{pSer}^{63}$ - Jun $(\boldsymbol{D})$ and cJun $(\boldsymbol{E})$ normalized to the amount of JNK. Data are shown as mean \pm SEM. $n=5 ;{ }^{* *} p<0.01$, two-way ANOVA followed by Bonferroni's post hoc test.

Electrophysiology. Extracellular recordings were performed as described previously (Lawrence et al., 2014). Hippocampi of wild-type or mutant mice (8-12 weeks old) were rapidly removed and briefly chilled in icecold aCSF containing the following (in $\mathrm{mm}$ ): $130 \mathrm{NaCl}, 3.5 \mathrm{KCl}, 10$ glucose, $1.25 \mathrm{NaH}_{2} \mathrm{PO}_{4}, 2.0 \mathrm{CaCl}_{2}, 1.5 \mathrm{MgSO}_{4}$, and $24 \mathrm{NaHCO}_{3}$ (equilibrated with $95 \% \mathrm{O}_{2} / 5 \% \mathrm{CO}_{2}, \mathrm{pH}$ 7.4). Transverse slices $350 \mu \mathrm{m}$ thick were prepared with a Vibratome (Leica, VT1200S) and maintained at least $1 \mathrm{~h}$ in a holding chamber containing aCSF. The slices were then transferred to a recording chamber and perfused $(3 \mathrm{ml} / \mathrm{min})$ with aCSF at $32^{\circ} \mathrm{C}$. CA1 field EPSPs (fEPSPs) were recorded with a glass electrode filled with $3 \mathrm{~m} \mathrm{NaCl}$ (resistance 1-1.5 $\mathrm{M} \Omega$ ) by stimulating the Schaffer collateral fibers through a bipolar stimulating electrode. The slope of the initial rising phase $(20-60 \%$ of the peak amplitude) of the fEPSP was used as a measure of the postsynaptic response. Basal synaptic neurotransmission was studied by plotting stimulus strength or fiber volley against fEPSP slope to generate input/output (I/O) relationships. Pairedpulse facilitation was defined as the second fEPSP slope divided by the first at various interstimulus intervals $(10,50,90,130,170,210$, and 250 $\mathrm{ms})$. For the LTP and LTD measurements, a minimum of $20 \mathrm{~min}$ of baseline stimulation $(0.05 \mathrm{~Hz})$ was recorded every minute at an intensity that evoked a response $40 \%$ of the maximum response. The strong tetanic LTP induction protocol consisted of two $100 \mathrm{~Hz}$ tetani $(1 \mathrm{~s}$ each), with an interval of $20 \mathrm{~s}$ between tetani. The weak LTP induction protocol consisted of 900 pulses given at $10 \mathrm{~Hz}$. To induce NMDAR-dependent LTD, $1 \mathrm{~Hz}$ and $0.5 \mathrm{~Hz}$ single pulse stimuli were delivered for 15 and 30 min, respectively ( 900 stimuli). To induce mGluR-dependent LTD, slices were incubated with $100 \mu \mathrm{M}(\mathrm{S})-3,5$ - dihydroxyphenylglycine (DHPG; Tocris Bioscience, catalog \#0805) for $5 \mathrm{~min}$. For the depotentiation study, LTP was evoked by high-frequency stimulation (HFS) with two trains of $100 \mathrm{~Hz}$ (20 s between tetani). Ten minutes after LTP induction, depotentiation was induced by low-frequency stimulation (LFS) consisting of 900 pulses delivered at $1 \mathrm{~Hz}$ for $15 \mathrm{~min}$. fEPSP responses were recorded using a computer with WinLTP data acquisition software (WinLTP). For pharmacological studies, JNK-in-8 (Selleckchem, catalog \#S 4901; $6 \mu \mathrm{M}$ in aCSF with 10\% DMSO) or vehicle was applied for 20 min before testing and were maintained throughout the recording period.

For EPSC measurements, mice (6-10 weeks old) were anesthetized with isoflurane (Sigma-Aldrich, catalog \#792632) and perfused with icecold sucrose solution containing the following (in $\mathrm{mM}$ ): 200 sucrose, 20 glucose, $5 \mathrm{KCl}, 1.2 \mathrm{NaH}_{2} \mathrm{PO}_{4}, 25 \mathrm{NaHCO}_{3}, 0.5 \mathrm{CaCl}_{2}, 7 \mathrm{MgCl}_{2}, 1.3$ ascorbic acid, and 2.4 sodium pyruvate. Transverse sections $(350 \mu \mathrm{m})$ of the hippocampus were made and then incubated in aCSF at $34^{\circ} \mathrm{C}(20$ $\mathrm{min})$ before storing at room temperature. The aCSF for these experiments was composed of the following (in $\mathrm{mm}$ ): $125 \mathrm{NaCl}, 10$ glucose, $2.8 \mathrm{KCl}, 1 \mathrm{NaH}_{2} \mathrm{PO}_{4}, 26 \mathrm{NaHCO}_{3}, 2 \mathrm{CaCl}_{2}$, and $1.5 \mathrm{MgSO}_{4}$. Whole-cell voltage-clamp recordings were done at $32^{\circ} \mathrm{C}$ using an EPC-10 amplifier and Patchmaster acquisition software (HEKA Instruments, RRID: SCR_000034). Data acquisition and analysis was performed on a MacPro computer (Apple). Bicuculline ( $30 \mu \mathrm{M}$; Tocris Bioscience, catalog \#0130) and CGP-55845 ( $1 \mu \mathrm{M}$; Tocris Bioscience, catalog \#1248) were added to the aCSF to block $\mathrm{GABA}_{\mathrm{A}}$ and $\mathrm{GABA}_{\mathrm{B}}$ responses, respectively. Both sucrose and aCSF solutions were continually bubbled with $95 \% \mathrm{O}_{2} / 5 \%$ $\mathrm{CO}_{2}$. Patch pipettes were filled with an intracellular solution containing the following (in mM): 130 Cs-gluconate, $5 \mathrm{NaCl}, 0.5 \mathrm{CaCl}_{2}, 2 \mathrm{MgCl}_{2}, 10$ HEPES, $5 \mathrm{Cs}_{4}$ BAPTA, $2 \mathrm{MgATP}$, and $0.3 \mathrm{Na}_{2} \mathrm{GTP}$. The intracellular solution was titrated to $\mathrm{pH} 7.2$ and $280 \mathrm{mOsm}$. CAl principal cells were held at either -70 or $+50 \mathrm{mV}$ to measure the AMPA and NMDAR components of EPSCs, respectively. Stimulation of the Schaffer collaterals synapsing onto the CA1 cells was performed using an A360 stimulus 
isolation unit (World Precision Instruments) with a monopolar platinum iridium electrode placed in the stratum radiatum $\sim 350 \mu \mathrm{m}$ from the cell body. The stimulation intensity was adjusted to be $\sim 75 \%$ of the threshold for firing an action potential. Peak amplitudes were analyzed using Igor Pro version 6.3 (RRID:SCR000325).

Experimental design and statistical analysis. Data were analyzed statistically using StatView (SAS Institute) and GraphPad Prism 6 software. Student's $t$ test was used for comparing two conditions and ANOVA was used with Bonferroni post hoc test for comparing more than two conditions. All data are expressed as means \pm SEM. The accepted level of significance was $p \leq 0.05$, indicated by a single asterisk in the figures; $p$-values $\leq 0.01$ are indicated by double asterisks and $p$ values $\leq 0.001$ by triple asterisks.

\section{Results}

The aim of this study was to examine the impact of JIP1-regulated JNK activation on neuronal function and behavior. To accomplish this aim, we generated a novel mouse model harboring a T103A point mutation in the Jip1 gene (also known as Mapk8ip1). These mutant Mapk8ip1 $1^{\text {T103A/ }}$ T103A mice (JIP1 ${ }^{\mathrm{TA}}$ ) exhibit a profound defect in JIP1-mediated JNK activation compared with control JIP1 ${ }^{\text {WT }}$ animals. We therefore used this mutant mouse to determine the contribution of JIP1mediated JNK activation to NMDAdependent receptor signaling, memory, and synaptic plasticity.

\section{JIP1 expression in hippocampal neurons}

Our initial studies were designed to examine the expression of JIP1 protein in the hippocampus. Immunohistochemical staining of tissue sections demonstrated that JIP1 is expressed in the CA1, CA3, and the dentate gyrus (DG) regions of the hippocampus (Fig. 1A). JIP1 was primarily found on dendrites (colocalization with MAP2) and to a lesser extent on cell bodies (colocalization with NeuN) of the CA1/CA3 pyramidal and DG granule neurons (Fig. 1A).

We next examined the hippocampal architecture of JIP1 ${ }^{\text {TA }}$ and JIP1 ${ }^{\text {WT }}$ mice. Qualitative analysis of Nissl-stained (Fig. $1 B, C$ ) and Golgi-stained (Fig. $2 A$ ) coronal sections did not reveal differences in hippocampus morphology between JIP1 ${ }^{\mathrm{TA}}$ and JIP1 ${ }^{\text {WT }}$ mice. Moreover, analysis of basal and apical dendrites from Golgi-stained CA1 pyramidal neurons revealed no significant differences in dendritic branching, spine density, or spine type (Fig. $2 A-E$ ). In addition, the intensity and distribution of the neuronal marker NeuN $\left(t_{(6)}=0.89, p=0.41\right.$; two-tailed unpaired Student's $t$ test), the dendritic marker MAP2 $\left(t_{(6)}=0.71, p=\right.$ 0.51 ; two-tailed unpaired Student's $t$ test), the GABAergic interneuron marker GAD67 $\left(t_{(6)}=0.27, p=0.79\right.$; two-tailed unpaired Student's $t$ test), and the glial marker GFAP $\left(t_{(6)}=0.44\right.$, $p=0.67$; two-tailed unpaired Student's $t$ test) were similar in JIP $1^{\mathrm{TA}}$ and JIP1 ${ }^{\mathrm{WT}}$ mice (Fig. $1 B-D$ ). Collectively, these data
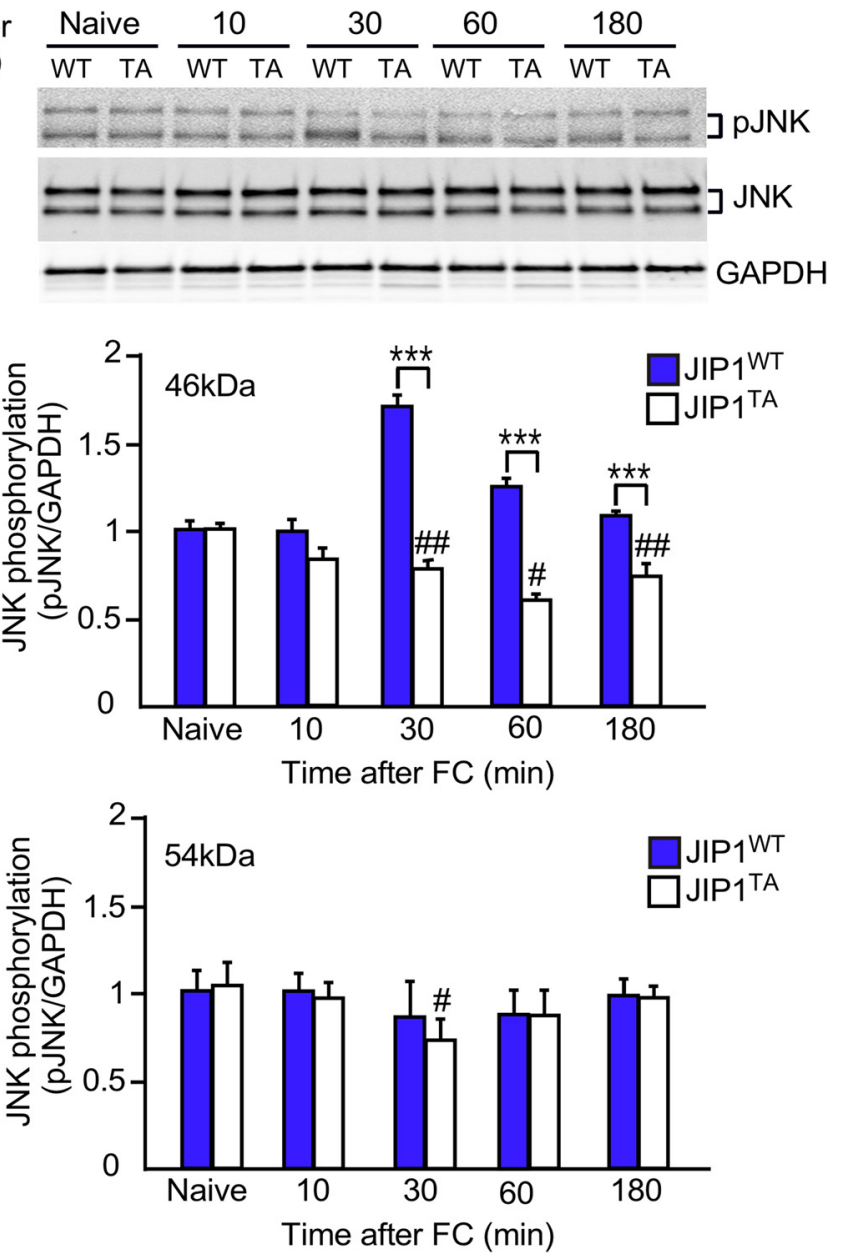

Figure 4. JIP1 ${ }^{T A}$ mice exhibit reduced JNK activation in the dorsal hippocampus after contextual fear conditioning. Dorsal ${ }^{* * *} p<0.001$, for JIP1 ${ }^{\text {TA }}$ compared with JIP1 ${ }^{\text {WT }}$ mice; $\# p<0.01$, \#\#p $<0.001$ compared with the naive control, two-way ANOVA, followed by Bonferroni's post hoc test.

indicate that the Thr ${ }^{103}$ Ala mutation in JIP1 did not cause detectable changes in basic hippocampus morphology.

\section{JIP1-mediated JNK activation in the hippocampus}

We have demonstrated previously that JIP $1^{\text {TA }}$ mice exhibit defects in metabolic stress-induced JNK activation in adipose tissue (Morel et al., 2010). To test whether the $\mathrm{Thr}^{103}$ Ala mutation in JIP1 also caused defects in JNK activation in neural tissue, we examined a model of JIP1-dependent JNK activation (kainate excitotoxicity) in the hippocampus. Examination of the DG after short-term exposure to kainate caused JIP1-dependent JNK activation and phosphorylation of the JNK substrate cJun and JIP1independent increased expression of cJun and cFos (Whitmarsh et al., 2001). We found that kainate caused a similar increase in cJun and cFos expression in JIP $1^{\text {TA }}$ and JIP $1^{\text {WT }}$ mice (Fig. $3 B, C$ ). In contrast, kainate caused increased cJun phosphorylation in JIP1 ${ }^{\text {WT }}$ but not JIP1 $1^{\text {TA }}$ mice (Fig. $3 A$ ). These data demonstrate that the Thr ${ }^{103}$ Ala mutation suppresses JIP1-mediated JNK activation in the hippocampus. Time course analysis confirmed that cJun phosphorylation in the hippocampus of kainate-stimulated JIP $1{ }^{\text {WT }}$ mice was strongly suppressed in JIP $1^{\text {TA }}$ mice after exposure to kainate (two-way ANOVA: genotype $F_{(1,32)}=15.11, p<$ 0.001 ; time $F_{(3,32)}=34.26, p<0.001$; genotype $\times$ time $F_{(3,32)}=$ 
A


G

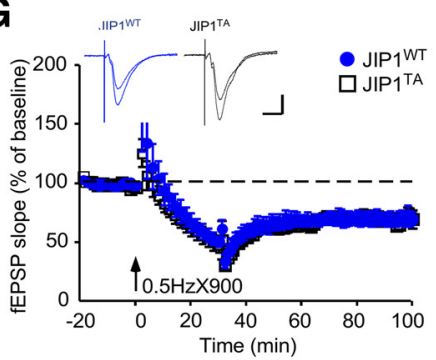

I



B

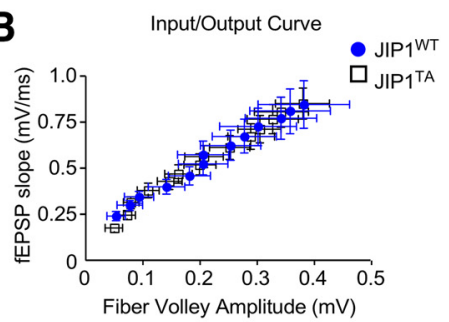

D



$\mathbf{F}$

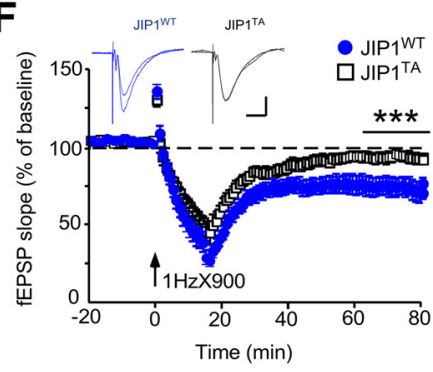

H
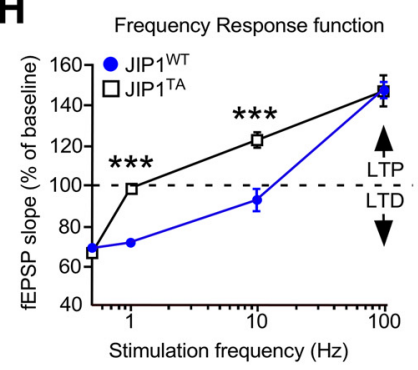

$\mathbf{J}$

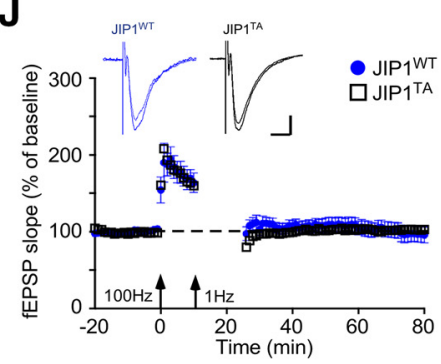

Figure 5. The threshold for LTP induction is reduced in JPP $1^{T A}$ mice. $A, B$, Basal synaptic transmission at Schaffer collateral-CA1 synapses, as assessed by measuring the fEPSP I/0 relationship ( $\boldsymbol{A}$ ) and the fEPSP slope to fiber volley relationship $(\boldsymbol{B})$, was similar in JIP $1^{\mathrm{TA}}$ slices ( $n=16$ slices, 13 mice) compared with slices obtained from JIP1 ${ }^{\mathrm{WT}}$ littermates ( $n=16$ slices, 12 mice). No statistically significant differences were found ( $p>0.05$, two-way repeated-measures ANOVA). C, fEPSPs from JIP1 ${ }^{\mathrm{TA}}(n=16$ slices, 13 mice) and JIP1 ${ }^{\text {WT }}$ ( $n=16$ slices, 12 mice) slices exhibited similar paired pulse facilitation. No statistically significant differences were found ( $p>0.05$, two-way repeated-measures ANOVA). D, HFS LTP was induced by two trains of $100 \mathrm{~Hz}$ stimulation (separated by a $20 \mathrm{~s}$ interval) to the Schaffer collaterals in slices from JIP1 ${ }^{\text {TA }}$ and JIP1 ${ }^{\text {WT }}$ mice $(n=10$ slices, 8 mice/genotype). Stimulation was delivered at time 0 (arrow). No statistically significant differences were found $(p>0.05$, Student's $t$ test). $\boldsymbol{E}$, An intermediate stimulation LTP protocol involved 900 pulses of $10 \mathrm{~Hz}$ stimuli delivered at time 0 . LTP induced at intermediate frequencies was significantly facilitated in slices taken from JIP1 ${ }^{T A}$ mice when compared with JPP ${ }^{\mathrm{WT}}$ controls ( $n=10$ slices, 9 mice/genotype). Statistically significant differences are indicated ${ }^{* * *} p<0.001$, Student's $t$ test). $\boldsymbol{F}$, LTD induced by LFS ( $1 \mathrm{~Hz}, 900$ pulses, $0-15$ min time) was significantly reduced in JIP1 ${ }^{\text {TA }}$ slices compared with JIP1 ${ }^{\text {WT }}$ slices ( $n=10$ slices, 10 mice/genotype). Statistically significant differences are indicated ${ }^{* * *} p<0.0001$, Student's $t$ test). G, LTD induced by $0.5 \mathrm{~Hz}$ stimulation ( $0.5 \mathrm{~Hz}, 900$ pulses, $0-30$ min time) was similar in JIP1 ${ }^{\mathrm{WT}}$ and JIP1 ${ }^{\mathrm{TA}}$ slices ( $n=14$ slices, 11 mice/genotype). No statistically significant differences were found $\left(p>0.05\right.$, Student's $t$ test). $\boldsymbol{H}$, Frequency-response function in JIP1 ${ }^{\top A}$ and JIP1 ${ }^{W T}$

5.05, $p=0.005$; Fig. $3 D, E)$. These data extend our previous finding that JIP1 ${ }^{\text {TA }}$ mice exhibit defects in JIP1-dependent JNK activation in adipose tissue (Morel et al., 2010) to demonstrate that JIP1 ${ }^{\mathrm{TA}}$ mice also exhibit profound defects in JIP1-mediated JNK activation in the hippocampus.

To test how JIP1-mediated JNK activation contributes to a physiologically relevant response, we examined the effect of contextual fear conditioning, which was shown previously to cause transient JNK activation in the dorsal hippocampus (Sherrin et al., 2010). Immunoblot analysis using antibodies to JNK and phosphoJNK was performed to assess changes in JNK activation in dorsal hippocampal extracts from JIP1 ${ }^{\mathrm{WT}}$ and JIP1 ${ }^{\mathrm{TA}}$ mice that were subjected to single-trial contextual fear conditioning. Extracts were prepared at various times after the single trial to correspond to the consolidation phase of contextual fear (Igaz et al., 2002). JNK immunoblot analysis detects the $46 \mathrm{kDa}$ (JNK1 $\alpha 1$ and JNK1 $\beta 1$ ) and $54 \mathrm{kDa}$ isoforms (JNK2 $\alpha 2$, JNK2 $\beta 2$, and JNK3 $\alpha 2$ ) in brain (Davis, 2000). We found that contextual fear conditioning caused an increase in $46 \mathrm{kDa}$ phospho-JNK in JIP $1^{\text {WT }}$ mice at $30 \mathrm{~min}(176 \pm 12 \%$ of naive control mice; Bonferroni post hoc test, $p<$ $0.001)$ and $60 \mathrm{~min}(127 \pm 8 \%$ of naive; Bonferroni post hoc test, $p=0.09$; Fig. 4). In contrast, we found that JIP $1^{\mathrm{TA}}$ mice exhibited decreased $46 \mathrm{kDa}$ phospho-JNK at $30 \mathrm{~min}(75 \pm 11 \%$ of naive; Bonferroni post hoc test, $p=0.011), 60 \mathrm{~min}(53 \pm 7 \%$ of naive; $p<0.001)$ and $180 \min (79 \pm$ $6 \%$ of naive; $p=0.009$ ) after contextual

\footnotetext{
$\leftarrow$

mice. The percentage change in synaptic strength from baseline in JIP1 ${ }^{\top A}$ and JIP1 ${ }^{\mathrm{WT}}$ mice at 50 - 60 min after stimulation at the indicated frequency is presented. Data are shown as mean \pm SEM. Magnitudes of LTP/LTD were calculated as the ratio of the average fEPSPs between 50 and $60 \mathrm{~min}$ and average baseline fEPSPs between $-20 \mathrm{~min}$ and $0 \mathrm{~min}$. Statistically significant differences are indicated ${ }^{* * *} p<0.001$, Student's $t$ test). $I$, mGluR-dependent LTP in hippocampal slices from $J I P 1^{T A}$ and JIP1 ${ }^{\text {WT }}$ mice. mGluR-LTD was induced by incubation of JIP ${ }^{\mathrm{TA}}$ and JIP1 ${ }^{\mathrm{WT}}$ slices with DHPG $(100 \mu \mathrm{m})$ for $5 \mathrm{~min}$ ( $n=10$ slices, 10 mice/genotype). Basal fEPSPs were recorded before LTD induction with DHPG. No statistically significant differences were found ( $p>0.05$, Student's $t$ test). $J$, Depotentiation is not affected in JIP1 ${ }^{\text {TA }}$ mice. HFS (100 Hz twice for $1 \mathrm{~s}$ with $20 \mathrm{~s}$ interval) followed by $1 \mathrm{~Hz}$ (15 min) stimulation 10 min later to the Schaffer collaterals produced similar depotentiation in slices from JIP1 ${ }^{\mathrm{TA}}$ and JIP1 ${ }^{\mathrm{WT}}$ mice ( $n=10$ slices, 10 mice/genotype). No statistically significant differences were found ( $p>0.05$, Student's $t$ test). The insets in $\boldsymbol{D}-\boldsymbol{J}$ show representative fEPSP responses obtained before and after LTP, LTD and depotentiation inducing stimuli. Calibration: $0.2 \mathrm{mV} / 10 \mathrm{~ms}$.
} 
fear conditioning (two-way ANOVA: genotype $F_{(1,50)}=15.11, p<0.001$; time $F_{(4,50)}=10.42, p<0.001$; genotype $\times$ time $F_{(4,50)}=22.11, p<0.001$; Fig. 4). These data demonstrate that the JIP1 Thr ${ }^{103}$ Ala mutation suppresses JNK activation caused by contextual fear conditioning.

\section{JIP1-mediated JNK activation suppresses NMDA-dependent synaptic plasticity}

JNK activation is associated with mechanistic changes in synaptic plasticity in the hippocampus (Wang et al., 2004; Chen et al., 2005; Zhu et al., 2005; Li et al., 2007; Yang et al., 2011). Therefore, synaptic plasticity may be altered by JIP1dependent JNK activation in the context of fear conditioning (Fig. 4). We therefore examined synaptic transmission in JIP1 ${ }^{\text {WT }}$ and JIP1 ${ }^{\text {TA }}$ mice.

Basal synaptic transmission at Schaffer collateral-CA1 synapses in JIP ${ }^{\text {WT }}$ and JIP1 ${ }^{\mathrm{TA}}$ mice was characterized through the I/O relationship of fEPSPs. Analysis revealed that the fEPSP slopes, plotted against the stimulation strength, were comparable in slices from JIP1 ${ }^{\text {WT }}$ and JIP1 ${ }^{\text {TA }}$ mice (two-way repeated-measures ANOVA: genotype $F_{(1,420)}=0.23, p=0.63$; amplitude $F_{(14,442)}=79.27, p<0.001$; genotype $\times$ amplitude $F_{(14,420)}=0.35, p=$ 0.63; Fig. 5A). Similarly, when the fEPSP slopes were plotted as a function of increasing fiber volley amplitudes, no differences between JIP $1^{\text {WT }}$ and JIP $1^{\text {TA }}$ mice were detected (Fig. $5 B$ ). Moreover, PPF, indicative of presynaptic plasticity (Zucker and Regehr, 2002), at Schaffer collateral-CA1 synapses from JIP1 ${ }^{\text {TA }}$ mice was similar to JIP1 ${ }^{\text {WT }}$ mice at several interpulse intervals (two-way repeated-measures ANOVA: genotype $F_{(1,223)}=0.08, p=0.78$; interval $F_{(6,223)}=13.56, p<0.001$; genotype $\times$ interval $F_{(8,208)}=0.15$, $p=0.98$; Fig. $5 C$ ). These data demonstrate similar basal synaptic transmission in the hippocampi of JIP1 ${ }^{\mathrm{TA}}$ and JIP1 ${ }^{\mathrm{WT}}$ mice.

To determine whether the JIP1 $\mathrm{Thr}^{103}$ Ala mutation affects NMDAR-dependent forms of synaptic plasticity (Citri and Malenka, 2008), LTP was measured using a tetanic HFS protocol ( 2 trains of $1 \mathrm{~s} 100 \mathrm{~Hz}$, separated by $20 \mathrm{~s}$ ). Similar potentiation was produced in both JIP $1^{\mathrm{WT}}$ and JIP $1^{\mathrm{TA}}$ mice (Fig. $5 D$; fEPSPs were potentiated to $145 \pm 7 \%$ for JIP1 ${ }^{\text {WT }}$ and $146 \pm 4 \%$ for JIP $1^{\text {TA }} ; t_{(18)}=0.12, p=0.89$; two-tailed unpaired Student's $t$ test), indicating that the ability to induce LTP with strong stimulation was unimpaired in JIP1 ${ }^{\mathrm{TA}}$ mice. We next investigated whether the threshold stimulation for induction of LTP (Hu et al., 2007) differed between JIP $1^{\text {WT }}$ and JIP $1^{\text {TA }}$ mice. A 900 pulse train of $10 \mathrm{~Hz}$ stimulation resulted in a modest, but detectable, degree of LTP in slices obtained from JIP ${ }^{\text {TA }}$ mice (Fig. $5 E ; 122 \pm$ $4 \%$ of baseline at $50-60 \mathrm{~min}$ after LTP induction), though with minimal posttetanic potentiation, whereas fEPSPs in JIP1 ${ }^{\text {WT }}$ slices were not potentiated (Fig. $5 E$; $92.1 \pm 5.5 \%$ of baseline; $t_{(18)}=$ $7.61, p<0.001$; two-tailed unpaired Student's $t$ test), with a trend toward depression. These data demonstrate that LTP could be induced at lower frequencies in JIP1 ${ }^{\mathrm{TA}}$ mice compared with JIP1 ${ }^{\text {WT }}$ mice.
Input/Output Curve B

PPF
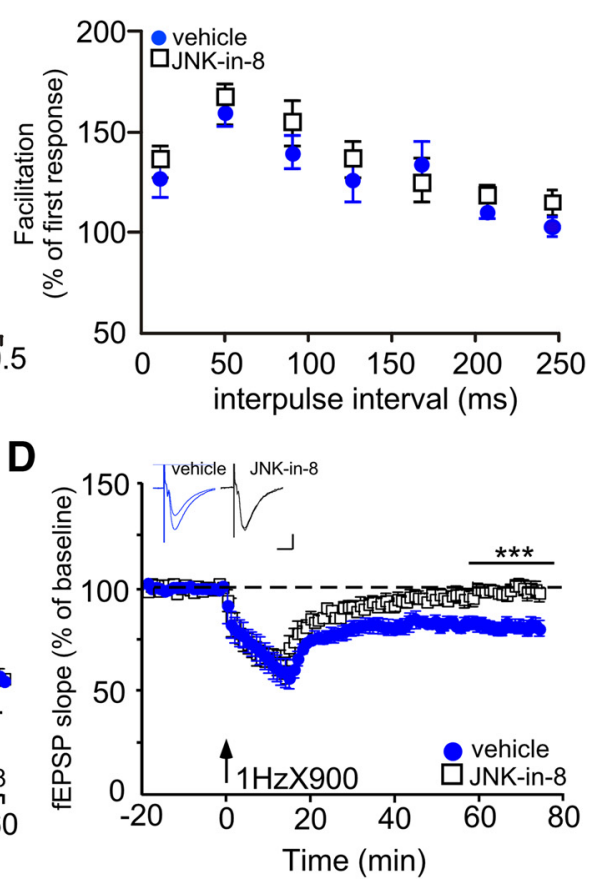

Figure 6. Inhibition of JNK signaling mimics the effect of JIP1 (Thr ${ }^{103} \mathrm{Ala}$ ) mutation on NMDAR-dependent LTD. $\boldsymbol{A}, \boldsymbol{B}, \mathrm{JNK}$-in-8 12 slices; $\boldsymbol{A}$ ). fEPSPs from vehicle-treated slices ( $n=12$ slices) and JNK-in-8 treated ( $n=12$ slices) slices exhibited similar PPF ( $\boldsymbol{B}$; $p>0.05$, two-way repeated-measures ANOVA). C, HFS-LTP was induced with a pair of $100 \mathrm{~Hz}$ tetani in the presence of either $\left({ }^{* * *} p<0.001\right.$, Student's $t$ test). The insets in $\boldsymbol{C}$ and $\boldsymbol{D}$ show representative fEPSP responses obtained before and after LTP/LTDinducing stimuli. Calibration: $0.2 \mathrm{mV} / 10 \mathrm{~ms}$.

We also examined the induction of NMDAR-dependent LTD (Collingridge et al., 2010) in JIP1 ${ }^{\mathrm{WT}}$ and JIP1 ${ }^{\mathrm{TA}}$ mice. We found that LFS consisting of 900 single pulses at $1 \mathrm{~Hz}$ for 15 min generated robust LTD in JIP1 ${ }^{\text {WT }}$ mice, but LTD was absent in JIP $1^{\text {TA }}$ mice (Fig. 5F; JIP1 ${ }^{\mathrm{WT}}$ mice, $72 \pm 2 \%$; JIP $1^{\mathrm{TA}}$ mice, $98 \pm 3 \%$; $p<$ $0.01 ; t_{(18)}=7.05, p<0.001$; two-tailed unpaired Student's $t$ test). In view of the similar posttetanic depression (initial dip) between JIP $1^{\text {WT }}$ and JIP $1^{\text {TA }}$ brain slices, we determined whether JIP $1^{\text {TA }}$ mice exhibit other forms of LTD. We therefore induced LTD by delivering the same number of single pulses (900) at $0.5 \mathrm{~Hz}$ for 30 min (Fig. 5G). This form of LTD also relies on NMDARs (Dudek and Bear, 1992), but depends to a greater degree on release of calcium from intracellular stores (Nakano et al., 2004). This LTD protocol produced equivalent depression in both JIP1 ${ }^{\mathrm{TA}}$ and JIP1 ${ }^{\mathrm{WT}}$ mice (Fig. $5 G$; JIP1 ${ }^{\mathrm{WT}}, 68 \pm 3 \%$; JIP1 ${ }^{\mathrm{TA}}, 66 \pm 2 \% ; t_{(26)}=$ $0.55, p=0.58$; two-tailed unpaired Student's $t$ test). These data indicate that disruption of JIP1-mediated JNK activation reduces the optimal frequency stimulation for LTD while enabling LTP at lower stimulation frequencies at Schaffer collateral-CA1 synapses (Fig. $5 H$ ).

Two different forms of LTD coexist at Schaffer collateral-CA1 synapses in the hippocampus, one dependent on NMDARs and another dependent on the activity of metabotropic glutamate receptors (mGluRs), specifically mGluR5 (Huber et al., 2001). Therefore, we next examined a possible effect of the JIP1 ${ }^{\mathrm{TA}} \mathrm{mu}$ tation on mGluR-dependent LTD. We found that a $5 \mathrm{~min}$ bath application of $100 \mu \mathrm{M}$ DHPG (a group I mGluR agonist) to acute slices resulted in a persistent depression of Schaffer 
A

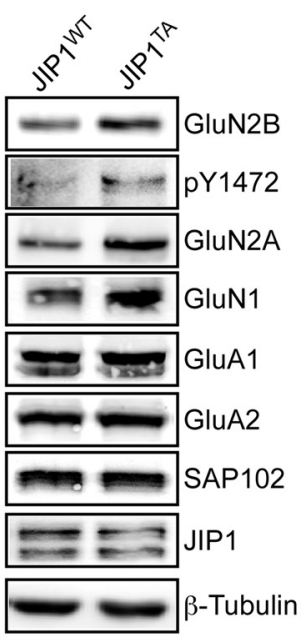

D

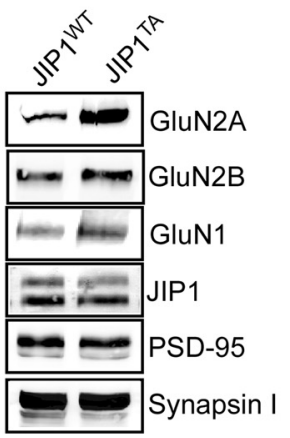

$\mathbf{F}$

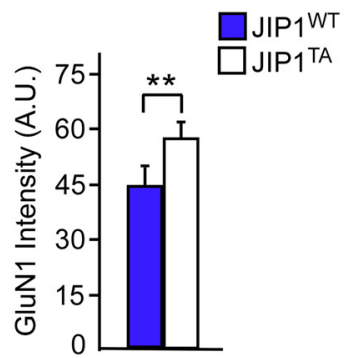

G

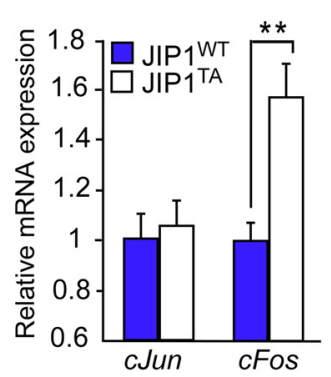

B



C

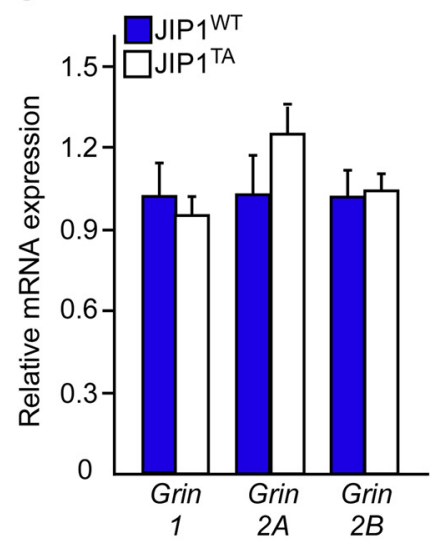

E



H

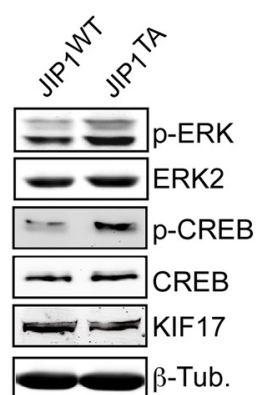

Figure 7. The JIP1 $1^{\mathrm{TA}}$ mutation promotes increased NMDAR expression and activity. $\boldsymbol{A}-\boldsymbol{C}$, Lysates prepared from the hippocampi of JIP1 $1^{\mathrm{TA}}$ and JIP1 ${ }^{\mathrm{WT}}$ mice were examined by immunoblot analysis by probing with antibodies to NMDA and AMPAR subunits, SAP102, JP1, and $\beta$-tubulin $(\boldsymbol{A})$. The number of NMDAR subunits in the hippocampus was determined and normalized to the amount of $\beta$-tubulin in each sample ( $\boldsymbol{B}$, mean $\pm \mathrm{SEM}, n=5$; ${ }^{* *} p<0.01$, Student's $t$ test). The amount of NMDAR subunit mRNA in the hippocampus was measured by qRT-PCR and normalized to the amount of Gapdh mRNA in each sample ( $\boldsymbol{C}$, mean $\pm \mathrm{SEM}, n=5 ; p>0.05$, Student's t test). $\boldsymbol{D}$, Enrichment of NMDAR subunits in the synaptoneurosome fraction of the hippocampus of JIP 1 WT and $J P 1^{T A}$ mice was examined by immunoblot analysis. $E, F$, Primary JIP $1^{\mathrm{WT}}$ and $J P{ }^{T A}$ hippocampal neurons were fixed and processed for immunofluorescence analysis under nonpermeabilized (left) and permeabilized (right) conditions. GluN1 surface and intracellular expression was examined by confocal microscopy (E). Quantitation of the cell surface expression of GluN1 in JIP1 ${ }^{\mathrm{TA}}$ and $J \mathbb{P} 1^{\mathrm{WT}}$ hippocampal neurons was performed using ImageJ software $(\boldsymbol{F})$. Data are shown as mean $\pm \mathrm{SEM} ; n=8 \sim 10 ;{ }^{* *} p<0.01$, Student's $t$ test. $\boldsymbol{G}$, The expression of $\mathrm{clun}$ and $c$ Fos $\mathrm{mRNA}$ in the hippocampus of JIP1 ${ }^{\mathrm{WT}}$ and JPP1 ${ }^{\mathrm{TA}}$ mice was normalized to the amount of Gapdh in each sample (mean $\pm \mathrm{SEM}, n=5 \sim 6$ ). Statistically significant differences are indicated ${ }^{* *} p<0.01$, Student's $t$ test). $\boldsymbol{H}$, Lysates prepared from the hippocampus of JIP1 ${ }^{\mathrm{WT}}$ and JIP1 ${ }^{\mathrm{TA}}$ mice were examined by immunoblot analysis with antibodies to phospho-ERK, ERK, phospho-CREB, CREB, KIF17, and $\beta$-Tubulin. The amount of phospho-ERK and phospho-CREB was quantitated (mean \pm SEM, $n=5$ ). Statistically significant differences are indicated (** $p<0.01$, Student's $t$ test). 
collateral-evoked responses that was comparable between JIP $1^{\text {TA }}$ and JIP1 ${ }^{\text {WT }}$ slices (Fig. 5I; $62 \pm 1 \%$ of baseline at 60 min after drug application for JIP $1^{\mathrm{TA}} \mathrm{vs}$ $65 \pm 8 \%$ for JIP1 ${ }^{\mathrm{WT}} ; t_{(18)}=0.68, p=$ 0.49; two-tailed unpaired Student's $t$ test). These results suggest that, whereas the JIP1 ${ }^{\text {TA }}$ mutation blocks the NMDARdependent forms of LTD, it does not affect the mGluR-dependent form.

Another important aspect of synaptic modification is synaptic depotentiation, namely that the synaptic potentiation could be subsequently reversed by LFS. In view of the finding that two trains of HFS at $100 \mathrm{~Hz}$ induced significant LTP in response to a $20 \mathrm{~s}$ intertetanus interval in both groups of mice (Fig. 5D), we used this HFS protocol followed by LFS $10 \mathrm{~min}$ later (900 pulses at $1 \mathrm{~Hz}$ ) to induce depotentiation (Fig. 5J). One hour after the LFS, the evoked responses in both JIP1 ${ }^{\text {WT }}$ and JIP $1^{\mathrm{TA}}$ mice dropped to the baseline level (100 $\pm 4 \%$ compared with baseline before the HFS for JIP1 ${ }^{\text {WT }}$, and $101 \pm 3 \%$ for JIP $1^{\text {TA }} ; t_{(18)}=0.23, p=0.82$; twotailed unpaired Student's $t$ test), indicating effective LFS-induced depotentiation in both genotypes.

We next tested whether application of a selective inhibitor of JNK would mimic the effects of the JIP1 $\mathrm{Thr}^{103}$ Ala mutation on NMDA-receptor dependent forms of LTP and LTD. Slices were obtained from wild-type mice and exposed either to the selective JNK inhibitor JNK-in-8 (6 $\mu \mathrm{M})$ or solvent (aCSF) for 20 min before stimulation protocols. The drug application was maintained throughout the recording period. Basal synaptic transmission was not affected by JNK-in-8, as indicated by the unchanged I/O relation (twoway repeated-measures ANOVA: genotype $\left.F_{(1,308)}=0.88, p=0.35\right)$; amplitude $F_{(14,308)}=61.73, p<0.001$; genotype $\times$ amplitude $\left.F_{(14,308)}=0.35, p=0.63\right)$ and unchanged PPF (two-way repeated-measures ANOVA: genotype $F_{(1,132)}=0.46$, $p=0.56)$; interval $F_{(6,132)}=42.12, p<$ 0.001 ; genotype $\times$ interval $F_{(6,132)}=1.17$, $p=0.11$; Fig. $6 A, B)$. In addition, inhibiting JNK activation in slices did not affect HFS LTP (Fig. 6C; 60 min after $2 \times 100$ Hz tetanization: $127 \pm 6 \%$ of baseline for vehicle-treated slices vs $125 \pm 5 \%$ for JNK-in-8-treated slices; $t_{(22)}=0.25, p=$ 0.81 ; two-tailed unpaired Student's $t$ test).

However, JNK inhibition prevented the induction of LTD using the $1 \mathrm{~Hz}$ stimulation protocol (Fig. 6D; vehicle-treated slices, $77 \pm 3 \%$; JNK-in-8-treated slices, $101 \pm 4 \%$; $p<0.05 ; t_{(18)}=$ $4.81, p<0.001$; two-tailed unpaired Student's $t$ test). The latter result closely parallels the result obtained for the JIP $1{ }^{\text {TA }}$ slices (cf. Fig. 5F). Therefore, these data confirm that JIP1-mediated JNK

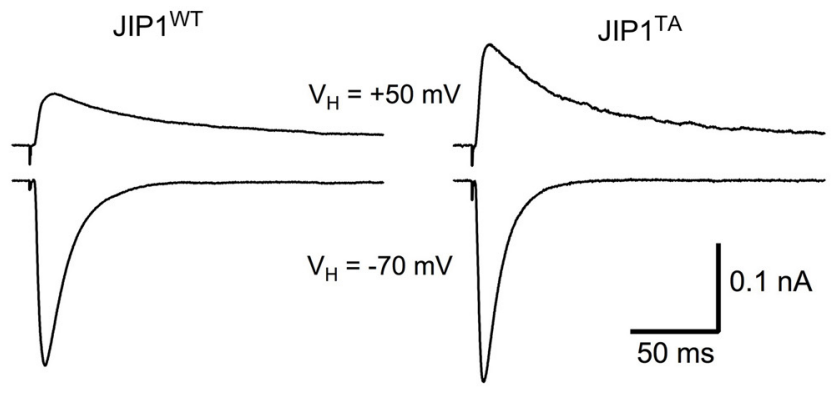

B

E



C

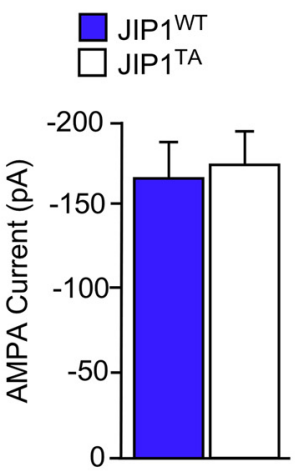

D

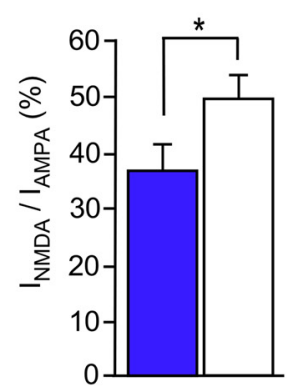

Figure 8. Increased synaptic NMDAR activity in hippocampal slices from JIP1 ${ }^{\mathrm{TA}}$ mice. $\boldsymbol{A}$, Whole-cell voltage-clamp traces depicting typical EPSCs elicited by stimulating the Schaffer collaterals while recording CA1 pyramidal cells from JIP1 ${ }^{\text {WT }}$ and JIP1 ${ }^{\text {TA }}$ hippocampal slices. Strong blockade of NMDARs at a holding potential of $-70 \mathrm{mV}$ by magnesium isolates the AMPA component (bottom traces). The $+50 \mathrm{mV}$ upper traces primarily represent the NMDA component because the traces were recorded $30-50 \mathrm{~ms}$ after stimulation when $\sim 90 \%$ of the AMPAR response had decayed. The traces show the increase in the NMDAR-mediated component for the JIP1 ${ }^{T A}$ group relative to JIP1 ${ }^{\text {WT }}$, whereas AMPAR mediated responses were not different. Traces depicted are averages of 20 sweeps for both NMDA and AMPAR-mediated components of JIP $1{ }^{\text {WT }}$ recorded from the same pyramidal neuron; 10 and 15 sweeps were used to produce the averages depicted for the NMDA and AMPAR-mediated components recorded from a $J I P 1^{T A}$ pyramidal neuron. $\boldsymbol{B}, \boldsymbol{C}$, Comparison of average NMDA and AMPAR currents. NMDAR-mediated currents $(\boldsymbol{B})$ were significantly greater in the JIP1 ${ }^{\text {TA }}$ group compared with the JIP1 ${ }^{\text {WT }}$ group (mean \pm SEM; $n=16 \sim 17$ cells; ${ }^{*} p<0.05$, Student's $t$ test), whereas average AMPAR-mediated currents $(\boldsymbol{C})$ did not differ. $\boldsymbol{D}$, NMDA to AMPAR current ratios were evaluated on a cell-by-cell basis. The JIP1 ${ }^{\text {TA }}$ ratios $\left(I_{\text {NMDA }} / I_{\text {AMPA }}\right)$ were larger than ratios measured from neurons in the JIP1 ${ }^{\text {WT }}$ group (mean \pm SEM; $n=$ $16 \sim 17$ cells; ${ }^{*} p<0.05$, Student's $t$ test). $\boldsymbol{E}, \boldsymbol{F}$, NMDA-stimulated gene expression in primary cultures of JIP1 ${ }^{\text {WT }}$ and JIP1 ${ }^{\text {TA }}$ hippocampal neurons was studied by treating neurons with $100 \mu \mathrm{m}$ NMDA plus $10 \mu \mathrm{m}$ glycine. The expression of $B d n f(\boldsymbol{E})$ and $C$ Fos (F) mRNA was quantitated by qRT-PCR and normalized to Gapdh (mean \pm SEM; $n=5 \sim 6$; ${ }^{* *} p<0.001$, two-way ANOVA followed by Bonferroni's post hoc test).

activation plays an essential, but differential, role in certain forms NMDA-receptor dependent synaptic plasticity.

\section{JIP1 ${ }^{\text {TA }}$ mice exhibit increased NMDAR signaling}

It is established that JIP scaffold proteins influence NMDAR activity (Kennedy et al., 2007). The induction of synaptic plasticity 


\section{Elevated Plus Maze}

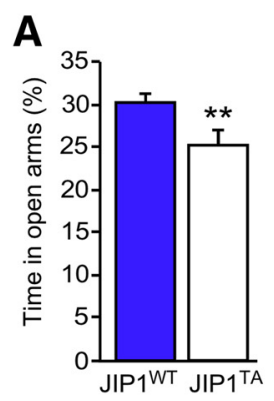

C

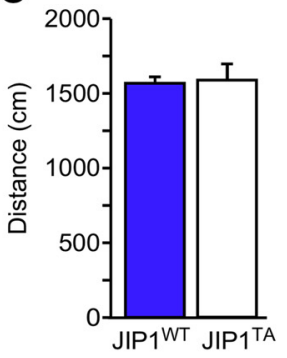

D

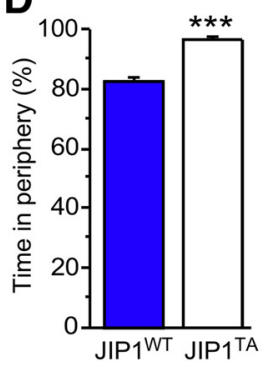

Open field Test



\section{Startle Response}


\section{Rotarod}

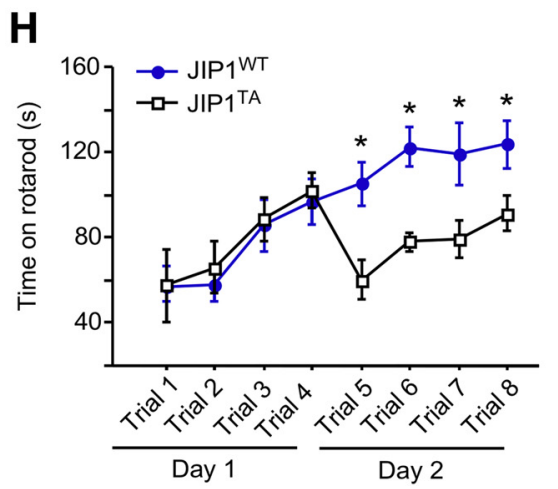

Figure 9. JIP1 ${ }^{\mathrm{TA}}$ mice display normal locomotor function, motor coordination, elevated anxiety-like behavior, and increased acoustic startle response. $\boldsymbol{A}$ - $\boldsymbol{C}$, Results of elevated plus maze test. $J I P 1^{\top A}$ mice show decreased time spent in open arms $(\boldsymbol{A})$ and increased time spent in closed arms $(\boldsymbol{B})$ relative to wild-type mice, indicative of elevated anxiety-like behaviors. In addition, JIP1 ${ }^{\top A}$ mice show normal activity as measured by total distance traveled (C). Data are shown as mean \pm SEM. $n=10 ;{ }^{* *} p<0.01$, Student's $t$ test. $\boldsymbol{D}, \boldsymbol{E}, 0$ pen-field test. JPP1 ${ }^{\text {TA }}$ mice show increased anxiety-like behavior in an open-field test. Mice were allowed to explore an open field for $5 \mathrm{~min}$. JP1 ${ }^{\mathrm{TA}}$ mice spent more time in the periphery $(\boldsymbol{D})$ and less time in the center region of the open field $(\boldsymbol{E})$, both indicators of increased levels of anxiety-like behavior in this test. Data are shown as mean \pm SEM. $n=10$; ${ }^{* * *} p<0.001$, Student's $t$ test. $\boldsymbol{F}$, JIP1 ${ }^{\text {TA }}$ mice showed an increased acoustic startle response for the $110 \mathrm{~dB}$ acoustic startle stimulus compared with JIP1 ${ }^{\text {WT }}$ mice (mean $\pm S E M ; n=8 ;{ }^{*} p<0.05$, two-way repeated-measures ANOVA followed by Bonferroni's post hoc comparisons tests). G, No significant differences in PPI for the 74,80 , and $86 \mathrm{~dB}$ pre-pulse sound levels followed by a $110 \mathrm{~dB}$ startle stimulus were observed between JIP1 ${ }^{\mathrm{TA}}$ and JIP1 ${ }^{\text {WT }}$ mice (mean \pm SEM; $n=$ $8 ; p>0.05$, two-way repeated-measures ANOVA followed by Bonferroni's post hoc test. $\boldsymbol{H}, J I P 1{ }^{\mathrm{TA}}$ mice have normal balance and motor coordination, but impaired skill learning on the rotarod. Mice received four trials on day 1 (trials 1-4) and day 2 (trials 5-8). The duration of balance or latency to fall (4-40 rpm over 5 min) was recorded. Mice were trained on day 1 to establish baseline performance and retested $24 \mathrm{~h}$ later to measure skill learning. Both JIP1 ${ }^{\mathrm{TA}}$ and JIP1 ${ }^{\mathrm{WT}}$ mice exhibited increased skill in maintaining balance on the rotarod over the first four trials on day $1.0 \mathrm{n}$ day $2, \mathrm{JIP} 1^{\mathrm{TA}}$ mice failed to display motor coordination achieved after the day 1 , indicative of impaired motor learning in the rotarod task. Data are shown as mean $\pm \mathrm{SEM} ; n=8 ;{ }^{*} p<0.05$, two-way repeated-measures ANOVA followed by Bonferroni's post hoc test.

at lower stimulation frequencies detected in JIP1 ${ }^{\mathrm{TA}}$ mice compared with JIP1 ${ }^{\text {WT }}$ mice (Fig. 6) may therefore be mediated by changes in NMDAR signaling. Indeed, we found increased expression of NMDAR subunits GluN1 $\left(t_{(8)}=2.66, p=0.029\right.$; two-tailed unpaired Student's $t$ test), GluN2A $\left(t_{(8)}=2.85, p=\right.$ 0.037; two-tailed unpaired Student's $t$ test), and GluN2B proteins $\left(t_{(8)}=2.65, p=0.027\right.$; two-tailed unpaired Student's $t$ test; but not mRNA) in the whole hippocampus of JIP $1^{\mathrm{TA}}$ mice compared with JIP1 ${ }^{\text {WT }}$ mice (Fig. $7 A-C$ ). Control studies detected no differences in the expression of the AMPAR subunits GluA1 and GluA2 (Fig. 7A). The increased expression of NMDAR subunits was also detected in hippocampal synaptoneurosomes (Fig. 7D) and by increased cell surface detection of GluN1 by immunofluorescence analysis of hippocampal neurons $\left(t_{(16)}=2.85, p=\right.$ 0.012; two-tailed unpaired Student's $t$ test; Fig. $7 E, F)$ cultured from JIP $1^{\mathrm{TA}}$ mice compared with JIP $1{ }^{\mathrm{WT}}$ mice. These changes were associated with biochemical evidence of increased NMDAR activity through assessment of downstream signaling changes, including increased GluN2B Tyr ${ }^{1472}$ phosphorylation (Salter and Kalia, 2004; Fig. 7A), increased cFos mRNA expression $\left(t_{(9)}=\right.$ $3.31, p=0.009$; two-tailed unpaired Student's $t$ test; Bading et al., 1993; Fig. $7 G)$, ERK phosphorylation $\left(t_{(8)}=3.11, p=0.017\right.$; two-tailed unpaired Student's $t$ test; Xia et al., 1996; Fig. $7 H$ ), and
CREB phosphorylation $\left(t_{(8)}=5.25, p=0.008\right.$; two-tailed unpaired Student's $t$ test; Ginty et al., 1993; Fig. $7 H$ ). Control experiments demonstrated that the expression of KIF17, a microtubule motor that transports GluN2B vesicles and regulates synaptic plasticity (Yin et al., 2011, 2012), was similar in JIP1 ${ }^{\text {WT }}$ and JIP $1^{\mathrm{TA}}$ mice (Fig. $7 H$ ). Together, these data indicate that JIP1 ${ }^{\mathrm{TA}}$ mice may exhibit increased NMDAR signaling in the hippocampus compared with JIP1 ${ }^{\text {WT }}$ mice.

To test functionally whether NMDAR signaling was increased in JIP $1^{\mathrm{TA}}$ mice compared with JIP1 ${ }^{\mathrm{WT}}$ mice, we examined EPSCs via whole-cell recordings of CA1 pyramidal cells in acute hippocampus slices. For CA1 pyramidal cells held under voltage clamp at $-70 \mathrm{mV}$, the response to Schaffer collateral stimulation is primarily mediated by AMPARs. The NMDAR-mediated component of EPSCs is readily distinguished from the AMPAR component by measuring current responses at a membrane potential of $+50 \mathrm{mV} \sim 30 \mathrm{~ms}$ after stimulation, when $\sim 90 \%$ of the AMPAR response has decayed (Liao et al., 1995; Myme et al., 2003). We found that the average NMDAR-mediated peak EPSC was 1.6-fold larger in JIP1 ${ }^{\mathrm{TA}}$ mice compared with JIP1 ${ }^{\mathrm{WT}}$ mice $\left(t_{(31)}=2.41, p=0.022\right.$; two-tailed unpaired Student's $t$ test; Fig. $8 A, B)$, whereas the average peak amplitude of the AMPARmediated EPSCs were similar in JIP $1^{\mathrm{TA}}$ and JIP1 ${ }^{\text {WT }}$ mice $\left(t_{(31)}=\right.$ 
$0.28, p=0.77$; two-tailed unpaired Student's $t$ test; Fig. $8 A, C$ ). These findings were reflected in the NMDAR/AMPAR peak current ratio calculated for each cell tested. JIP1 $^{\text {WT }}$ mice had a NMDA/AMPAR ratio of $37 \pm 4 \%$, whereas JIP $1^{\mathrm{TA}}$ mice yielded a significantly larger ratio of $50 \pm 4 \%\left(t_{(31)}=2.21, p=0.038\right.$; twotailed unpaired Student's $t$ test; Fig. $8 D$ ). This analysis demonstrated that NMDAR signaling is increased in JIP1 ${ }^{\mathrm{TA}}$ hippocampal neurons compared with those of JIP $1^{\text {WT }}$ mice. To confirm this conclusion, we examined NMDAR-stimulated gene expression in primary JIP $1^{\mathrm{TA}}$ and JIP1 ${ }^{\text {WT }}$ hippocampal neurons. We found that NMDA-induced expression of brainderived neurotrophic factor (Bdnf) mRNA (Ghosh et al., 1994; Tabuchi et al., 2000) and $c$ Fos mRNA (Bading et al., 1993; Xia et al., 1996) by JIP1 ${ }^{\text {TA }}$ neurons were increased when compared with JIP1 ${ }^{\text {WT }}$ neurons ([two-way ANOVA: genotype $F_{(1,29)}=70.26, p<0.001$; time $F_{(2,29)}=$ $39.7, p<0.001$; genotype $\times$ time $F_{(2,29)}=$ 14.91, $p<0.001$; for $B d n f \mathrm{mRNA}$ ]; [two-way ANOVA: genotype $F_{(1,30)}=17.67, p<0.001$; time $F_{(2,30)}=182.1, p<0.001$; genotype $\times$ time $F_{(2,30)}=7,98, p<0.001$; for $c F o s$ mRNA]; Fig. $8 E, F)$. Together, these data indicate that the increased NMDAmediated signaling detected in the JIP $1^{\text {TA }}$ hippocampus is due to enhanced NMDAR activity in individual neurons.

\section{JIP1-mediated JNK activation in locomotor, sensory and emotional responses}

To address the possibility that increased NMDAR signaling in JIP $1^{\mathrm{TA}}$ mice compared with JIP1 ${ }^{\text {WT }}$ mice may cause behavioral changes, we first performed a battery of basic behavioral tests of CNS function on JIP $1^{\text {WT }}$ and JIP $1^{\text {TA }}$ mice. We found that anxiety-related behavior was increased in JIP1 ${ }^{\mathrm{TA}}$ mice. For example, JIP1 ${ }^{\mathrm{TA}}$ mice in an elevated plus maze spent less time in the open arms, compared with JIP1 ${ }^{\text {WT }}$ mice $\left(t_{(18)}=2.79, p=0.012\right.$; two-tailed unpaired Student's $t$ test), with no changes in locomotor activity $\left(t_{(18)}=0.76, p=0.45\right.$; two-tailed unpaired Student's $t$ test; Fig. $9 A-C)$. Moreover, JIP $1^{\mathrm{TA}}$ mice spent significantly less time in the center $\left(t_{(18)}=5.40, p<0.001\right.$; two-tailed unpaired Student's $t$ test $)$ and more in the periphery $\left(t_{(18)}=6.46, p<0.001\right.$; twotailed unpaired Student's $t$ test) during an open-field test compared with JIP1 ${ }^{\text {WT }}$ animals (Fig. 9D, E). Consistent with previous reports (Grillon et al., 1998), elevated anxiety in JIP1 ${ }^{\text {TA }}$ mice was accompanied by an enhancement of the startle response to strong acoustic stimuli (two-way repeated-measures ANOVA: genotype $F_{(1,42)}=5.42, p=0.035$; stimulus $F_{(3,42)}=105.42, p<0.001$; genotype $\times$ stimulus $=9.25, p<0.001$; Fig. $9 F)$. No changes in sensorimotor gating (pre-pulse inhibition) were observed (two-way


D
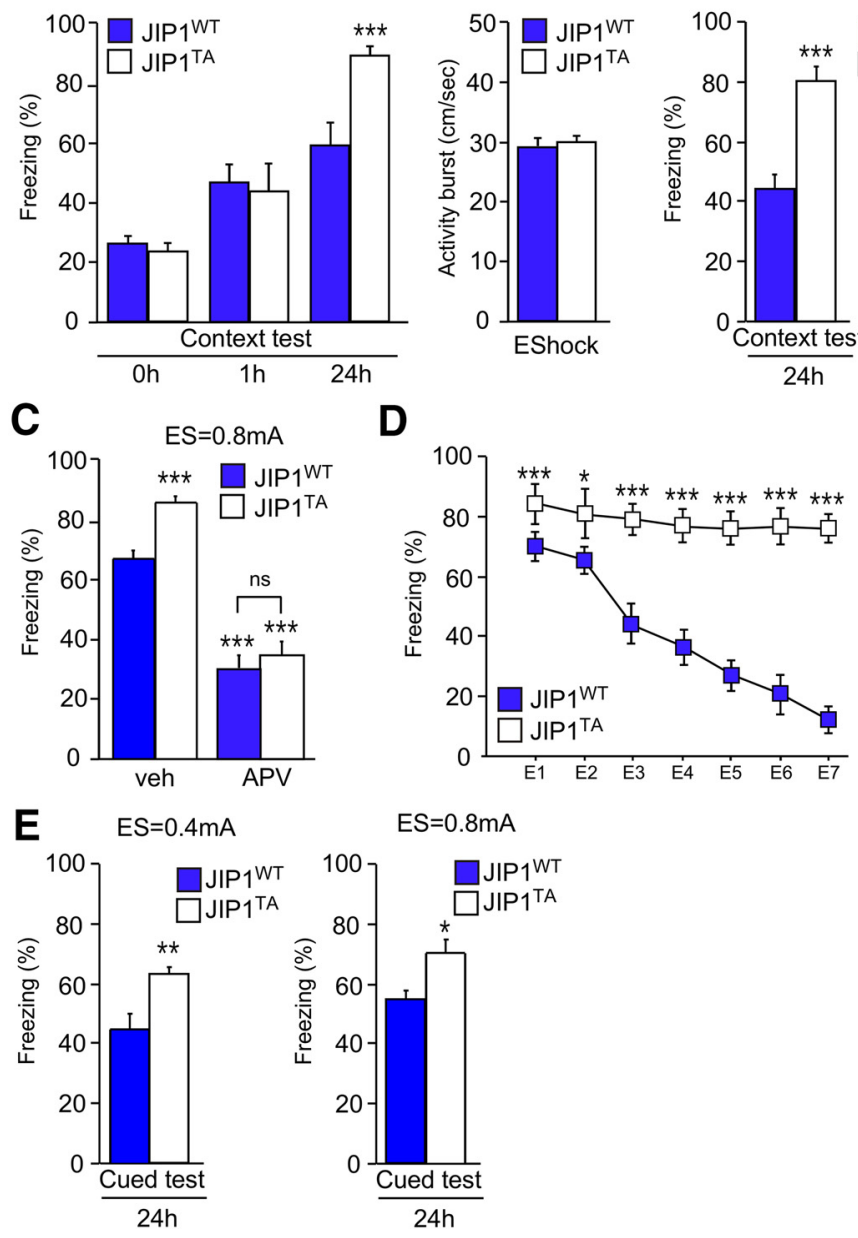

Figure 10. JIP1 ${ }^{\mathrm{TA}}$ mice display enhanced contextual fear and impaired fear extinction. $\boldsymbol{A}$, "Strong" (0.8 $\mathrm{mA}$ electric shock) training demonstrated that JIP $1^{\top A}$ and JIP $1{ }^{W T}$ littermate mice exhibited similar contextual freezing when tested immediately after training or $1 \mathrm{~h}$ later, but the JIP1 ${ }^{\mathrm{TA}}$ mice froze more than JIP1 ${ }^{\mathrm{WT}}$ mice at $24 \mathrm{~h}$ after training (left). Foot-shock reactivity during fear-conditioning training did not significantly differ between JIP1 ${ }^{\mathrm{TA}}$ and JIP1 ${ }^{\mathrm{WT}}$ mice (right). Data are shown as mean \pm SEM. $n=10 \sim 11 ;{ }^{* * *} p<0.001$, Student's $t$ test. $\boldsymbol{B}$, "Weak" (0.4 mA electric shock) training demonstrated that JP1 ${ }^{\mathrm{TA}}$ mice $(n=14)$ exhibited contextual freezing that was similar to the "strong" training schedule, but JIP1 ${ }^{\text {WT }}$ mice $(n=14)$ displayed significantly less contextual fear conditioning at $24 \mathrm{~h}$ after training. Data are shown as mean \pm SEM. $n=14 ;{ }^{* * *} p<0.001$, Student's $t$ test. C, JPP ${ }^{\mathrm{TA}}$ and JP $1{ }^{\mathrm{WT}}$ littermate mice were infused with vehicle or the selective NMDAR antagonist APV (10 $\left.\mu \mathrm{g} / \mathrm{ml}\right)$ before "strong" $(0.8 \mathrm{~mA})$ contextual fear conditioning. The following day, there was a similar impairment in both genotypes in freezing levels to the conditioning context. Data are shown as mean \pm SEM. $n=10 ;{ }^{* * *} p<0.001$ vs JIP1 ${ }^{\text {WT + veh; }}$ n.s.; JIP1 ${ }^{\text {WT }+ \text { APV }}$ vS JPP1 ${ }^{\text {TA }+ \text { APV }}$; two-way ANOVA followed by Bonferroni's post hoc test. D, JIP1 ${ }^{\top \mathrm{TA}}$ and JIP1 ${ }^{\mathrm{WT}}$ littermate mice were trained by "strong" $(0.8 \mathrm{~mA}$ electric shock) contextual fear conditioning. Extinction began $24 \mathrm{~h}$ later and consisted of daily $3 \mathrm{~min}$ reexposures of mice to the conditioning context in the absence of shock. When compared with JIP1 ${ }^{\mathrm{WT}}$ littermates, IIP1 ${ }^{\mathrm{TA}}$ mice showed increased freezing behavior throughout extinction days 1-7 (E1-E7), indicating impaired extinction process in JIP1 ${ }^{\text {TA }}$ mice. Data are shown as mean \pm SEM. $n=10 ;{ }^{*} p<0.05,{ }^{* * *} p<0.001$; two-way repeated-measures ANOVA followed by Bonferroni's post hoc test. $\boldsymbol{E}$, "Weak" ( $0.4 \mathrm{~mA}$ electric shock; left) and "strong" ( $0.8 \mathrm{~mA}$; right) cued fear training, consisting of a single pair of cue (tone) and shock, demonstrated that JIP ${ }^{\mathrm{TA}}$ and JIP $1^{\text {WT }}$ mice exhibited enhanced conditioned freezing to a cue (tone) when tested $24 \mathrm{~h}$ after training. Data are shown as mean \pm SEM. $n=11 ;{ }^{*} p<0.05,{ }^{* *} p<0.01$, Student's $t$ test.

repeated-measures ANOVA: genotype $F_{(1,28)}=0.13, p=0.722$; Fig. $9 G)$. We also found that "fast" improvement in motor coordination on the accelerating rotarod was comparable between JIP 1 WT and JIP $1^{\text {TA }}$ mice. However, during the second day of rotarod training JIP $1^{\mathrm{TA}}$ mice did not display improved "slow" skill learning, unlike JIP $1^{\text {WT }}$ mice, as indicated by significant genotype $\times$ trial interaction value (two-way repeated-measures ANOVA: genotype $\left.F_{(1,98)}=4.84, p=0.045\right)$, trial $F_{(7,98)}=7.73$, $p<0.001$; genotype $\times \operatorname{trial} F_{(7,98)}=3.34, p=0.003$; Fig. $\left.9 H\right)$. Together, these data demonstrate that JIP $1^{\mathrm{TA}}$ mice have normal sensory and motor activity and attention function. However, 

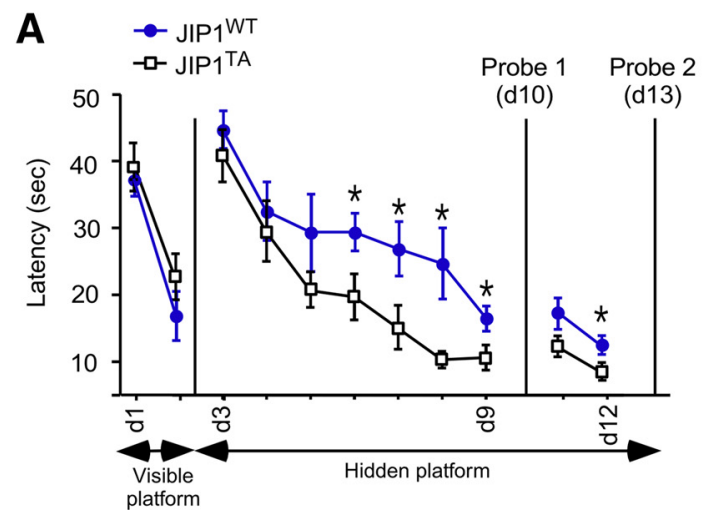

B

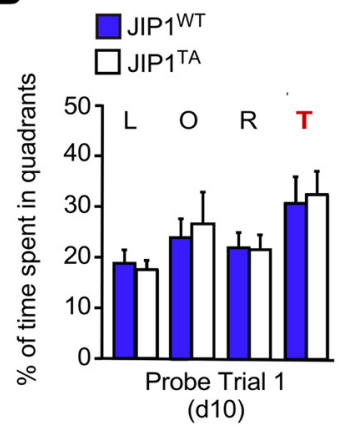

$\mathbf{E}$

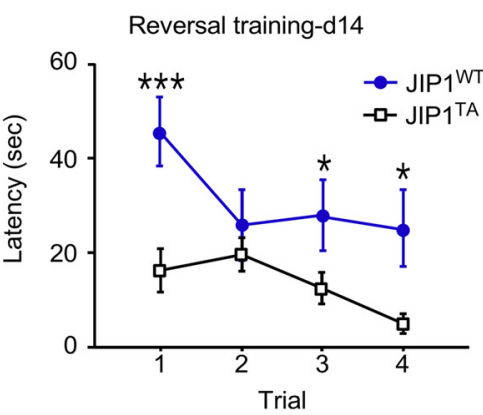

C

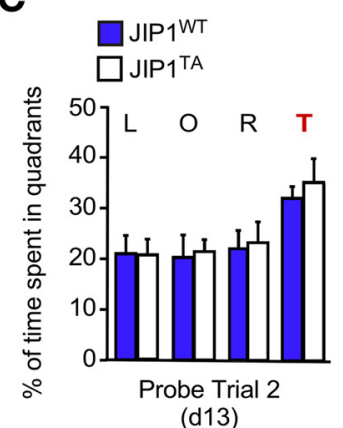

$\mathbf{F}$
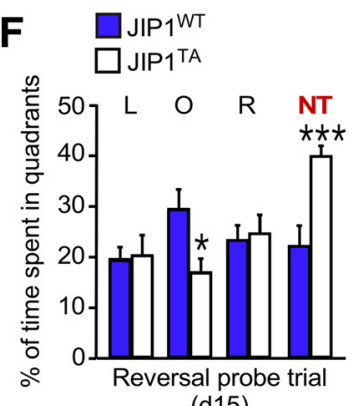

(d15)

Figure 11. $J I P 1^{\top A}$ mice exhibit enhanced acquisition and reversal learning in the MWM test. $A-C, J I P 1^{\top A}$ and JIP1 ${ }^{W T}$ littermate mice learned the visible platform task (day 1 and 2), as indicated by reductions in escape time during training. The mice were then trained to find a hidden platform during the next $7 \mathrm{~d}$. JPP $1{ }^{\mathrm{TA}}$ mice showed faster escape latencies at days $6-9$ of training compared with JIP $1{ }^{\text {WT }}$ littermates $(\boldsymbol{A})$. A first probe test (day 10) was conducted $24 \mathrm{~h}$ after the completion of training. No significant differences in percentage time spent in the target quadrant ( $\mathrm{T}$ ) between $J I P{ }^{T A}$ and JIP1 ${ }^{\text {WT }}$ mice were observed $(B)$. The mice were then subjected to $2 \mathrm{~d}$ of additional training (days $11-12$ ) and a second probe trial was performed $24 \mathrm{~h}$ later. No significant differences between JIP $1{ }^{T A}$ and JIP1 ${ }^{\text {WT }}$ mice were observed during second probe trial (C). Data are shown as mean \pm SEM. $n=14 ;{ }^{*} p<0.05$, $f$ (two-way repeated-measures ANOVA, followed by Bonferroni's post hoc test. $\boldsymbol{D}-\boldsymbol{F}$, Twenty-four hours after the second probe test, the platform was moved to the opposite quadrant in the pool and mice were trained for four trials (day 14 , reversal learning). In this new setting, JIP ${ }^{\mathrm{TA}}$ mice displayed shorter escape time to find newly placed platform (NT) compared with JP1 $1{ }^{\mathrm{WT}}$ littermate mice (E). The probe test for reversal training was conducted $24 \mathrm{~h}$ after the completion of new platform training (day 15). Analysis of the time spent in the quadrants revealed that JIP1 ${ }^{\mathrm{TA}}$ mice spent significantly more time in the NT than JPP ${ }^{\mathrm{WT}}$ mice $(\boldsymbol{F})$. Data are shown as mean \pm SEM. $n=14 ;{ }^{*} p<0.05,{ }^{* * *} p<0.001$, two-way repeated-measures ANOVA $(\boldsymbol{E})$ and two-way ANOVA $(\boldsymbol{F})$ followed by Bonferroni's post hoc tests.

JIP1 ${ }^{\mathrm{TA}}$ mice displayed increased levels of anxiety-related behaviors and altered skill learning.

\section{Improved extinction-resistant contextual fear memory in JIP1 ${ }^{\mathrm{TA}}$ mice}

Contextual fear conditioning triggers JIP1-dependent JNK activation in the hippocampus (Fig. 4). Moreover, JNK activation in the hippocampus is implicated in some forms of hippocampusdependent memory (Sherrin et al., 2011). We therefore compared JIP1 ${ }^{\mathrm{WT}}$ and JIP1 ${ }^{\mathrm{TA}}$ mice to determine whether JIP1-mediated JNK activation is required for the behavioral response to contextual fear conditioning. The mice received either "weak" $(0.4 \mathrm{~mA}$ shock) or "strong" ( $0.8 \mathrm{~mA}$ shock) training and were then reexposed to the chamber $24 \mathrm{~h}$ later to assess long-term fear memory (Shalin et al., 2006). The two training procedures were used to adjust for nociceptive sensitivity and also to test whether a "weak" stimulation protocol similar to one that facilitated synaptic plasticity (cf. Fig. $5 E$ ) results in enhanced hippocampal memory in JIP1 ${ }^{\mathrm{TA}}$ mice. JIP $1^{\mathrm{TA}}$ and JIP $1^{\mathrm{WT}}$ mice showed no differences in freezing or activity during the exploration period before the footshock (data not shown), or after the $0.8 \mathrm{~mA}$ foot-shock delivery $\left(t_{(19)}=0.46, p=0.65\right.$; two-tailed unpaired Student's $t$ test; Fig. $10 A$, right). Significantly enhanced contextual freezing of JIP $1^{\text {TA }}$ mice compared with JIP1 ${ }^{\text {WT }}$ controls was found $24 \mathrm{~h}$ after "strong" training (Fig. 10A, left; mean percentage freezing: $\mathrm{JIP} 1^{\mathrm{TA}}=85 \pm 3 \%$; JIP $1^{\mathrm{WT}}=59 \pm 4 \% ; t_{(19)}=5.11, p<0.001$; two-tailed unpaired Student's $t$ test). This enhancement of contextual fear was more pronounced in JIP1 ${ }^{\mathrm{TA}}$ mice when the "weak" paradigm was used (Fig. 10B; mean percentage freezing: $\mathrm{JIP} 1^{\mathrm{TA}}=81 \pm 4 \% ; \mathrm{JIP} 1^{\mathrm{WT}}=44 \pm 5 \% ; t_{(26)}=5.26, p<0.001$; two-tailed unpaired Student's $t$ test). We next investigated shortterm memory by testing JIP1 ${ }^{\mathrm{TA}}$ and JIP ${ }^{\mathrm{WT}}$ mice immediately or $1 \mathrm{~h}$ after the "strong" conditioning paradigm. We found that JIP $1^{\text {TA }}$ and JIP1 ${ }^{\text {WT }}$ mice displayed similar responses in the both contextual tests $\left(t_{(20)}=0.18, p=0.85 ; 0 \mathrm{~h}\right.$ after conditioning, two-tailed unpaired Student's $t$ test; $t_{(26)}=0.11, p=0.75 ; 1 \mathrm{~h}$ after conditioning, two-tailed unpaired Student's $t$ test; Fig. 10A, left). Therefore, JIP $1^{\mathrm{TA}}$ and JIP $1{ }^{\mathrm{WT}}$ mice did not differ in exploration activity, nociceptive reaction to electric shock, postshock freezing response, or short-term fear memory. These findings also indicate that the increased anxiety phenotype observed with the JIP $1^{\mathrm{TA}}$ mice does not appear to fundamentally affect shockinduced and postshock behaviors, including contextual fear conditioning and learning (see also Fig. 11). Nevertheless, JIP1 ${ }^{\text {TA }}$ mice exhibited increased long-term fear memory compared with JIP1 ${ }^{\text {WT }}$ mice (Fig. $10 A, B$ ).

We then tested whether contextual fear memory is affected differentially in JIP $1^{\mathrm{TA}}$ and JIP $1^{\mathrm{WT}}$ mice after antagonism of the NMDARs. JIP $1{ }^{\mathrm{TA}}$ and JIP $1{ }^{\mathrm{WT}}$ mice were implanted with cannulae into the dorsal hippocampus and subjected to contextual fear conditioning. A selective NMDAR antagonist, APV $(10 \mu \mathrm{g} / \mathrm{ml}$; $0.5 \mathrm{ml}$ ) or solvent (aCSF) was infused into the dorsal hippocampus 15 min before training. Both JIP1 ${ }^{\mathrm{TA}}$ and JIP $1^{\mathrm{WT}}$ mice given APV showed substantially reduced freezing to context compared with mice that received aCSF before conditioning (two-way ANOVA: genotype $F_{(1,36)}=8.76, p=0.0054$; treatment $F_{(1,36)}=$ 
143.06, $p<0.001$; genotype $\times$ treatment $=5.29, p=0.027$; Fig. 10C). However, no differences between APV-treated JIP1 ${ }^{\text {TA }}$ mice and APV-treated JIP1 ${ }^{\text {WT }}$ mice were observed (Bonferroni post hoc test: $p=0.62$; Fig. 10C), indicating that the memory-facilitating effects observed in JIP1 ${ }^{\text {TA }}$ were mediated via activation of NMDARs. Together, these experiments show that blockade of JIP1-mediated JNK activation can improve contextual learning induced by a relatively mild learning protocol and that enhanced NMDAR function is required for this facilitatory effect of JIP $1^{\mathrm{TA}}$ mutation on learning.

Previous studies have demonstrated that activation of hippocampal NMDAR regulates fear extinction (Szapiro et al., 2003; Suzuki et al., 2004; Leaderbrand et al., 2014) and that NMDAR blockade can prevent fear extinction in a variety of fearrelated tasks (Santini et al., 2001; SotresBayon et al., 2007). Therefore, we extended our cognitive evaluation of JIP1 ${ }^{\mathrm{TA}}$ mice by assessing contextual fear extinction to further assess the link of JIP1-JNK activation through NMDARs. Conditioned JIP1 $1^{\mathrm{TA}}$ and JIP1 ${ }^{\mathrm{WT}}$ mice were subjected to brief ( $3 \mathrm{~min}$ ) daily extinction trials by nonreinforced placement in the training context for $7 \mathrm{~d}$ after contextual conditioning. During the extinction trials, JIP ${ }^{\mathrm{TA}}$ mice exhibited almost unchanged freezing responses, indicating nearly fully impaired extinction compared with JIP1 ${ }^{\text {WT }}$ mice (repeated-measures ANOVA: genotype $F_{(1,108)}=388.76, p<0.001$; time $F_{(6,108)}=$ $36.26, p<0.001 ; F_{(6,108)}$ genotype $\times$ time $=25.35, p<0.001$; Fig. 10D). Overall, these results indicate that the enhanced contextual fear observed in JIP $1^{\text {TA }}$ mice is strongly resistant to extinction.

Finally, cue-dependent fear conditioning was assessed in JIP1 ${ }^{\mathrm{TA}}$ mice and JIP1 ${ }^{\text {WT }}$ controls. As with contextual fear conditioning, mice received either a "strong" or a "weak" training protocol, both consisting of a single pairing of tone and shock at 0.8 and $0.4 \mathrm{~mA}$, respectively. In both protocols, JIP $1^{\mathrm{TA}}$ mice, compared with JIP1 ${ }^{\text {WT }}$ controls, displayed significantly more freezing when reexposed to the tone $24 \mathrm{~h}$ after training (Fig. 10E, left; mean percentage freezing: "weak" cued test- JIP $1{ }^{\mathrm{TA}}=66 \pm 3 \%$; JIP $1{ }^{\mathrm{WT}}=$ $44 \pm 4 \% ; t_{(20)}=3.71, p=0.01$; two-tailed unpaired Student's $t$ test; Fig. $10 E$, right; mean percentage freezing: "strong" cued test$\mathrm{JIP} 1^{\mathrm{TA}}=70 \pm 3 \%$; JIP1 ${ }^{\mathrm{WT}}=55 \pm 4 \% ; t_{(20)}=2.65, p=0.015$; two-tailed unpaired Student's $t$ test), indicating that JIP $1^{\mathrm{TA}}$ mice display memory enhancement in the fear learning tasks in a manner involving both amygdala- and hippocampus-dependent memory systems.

\section{Improved spatial learning in JIP1 ${ }^{\mathrm{TA}}$ \\ mice}

We next tested JIP1 ${ }^{\mathrm{TA}}$ and JIP1 ${ }^{\mathrm{WT}}$ mice using the MWM protocol, a hippocampus-dependent spatial memory task (Morris et al., 1982). During the hippocampus-independent visible portion
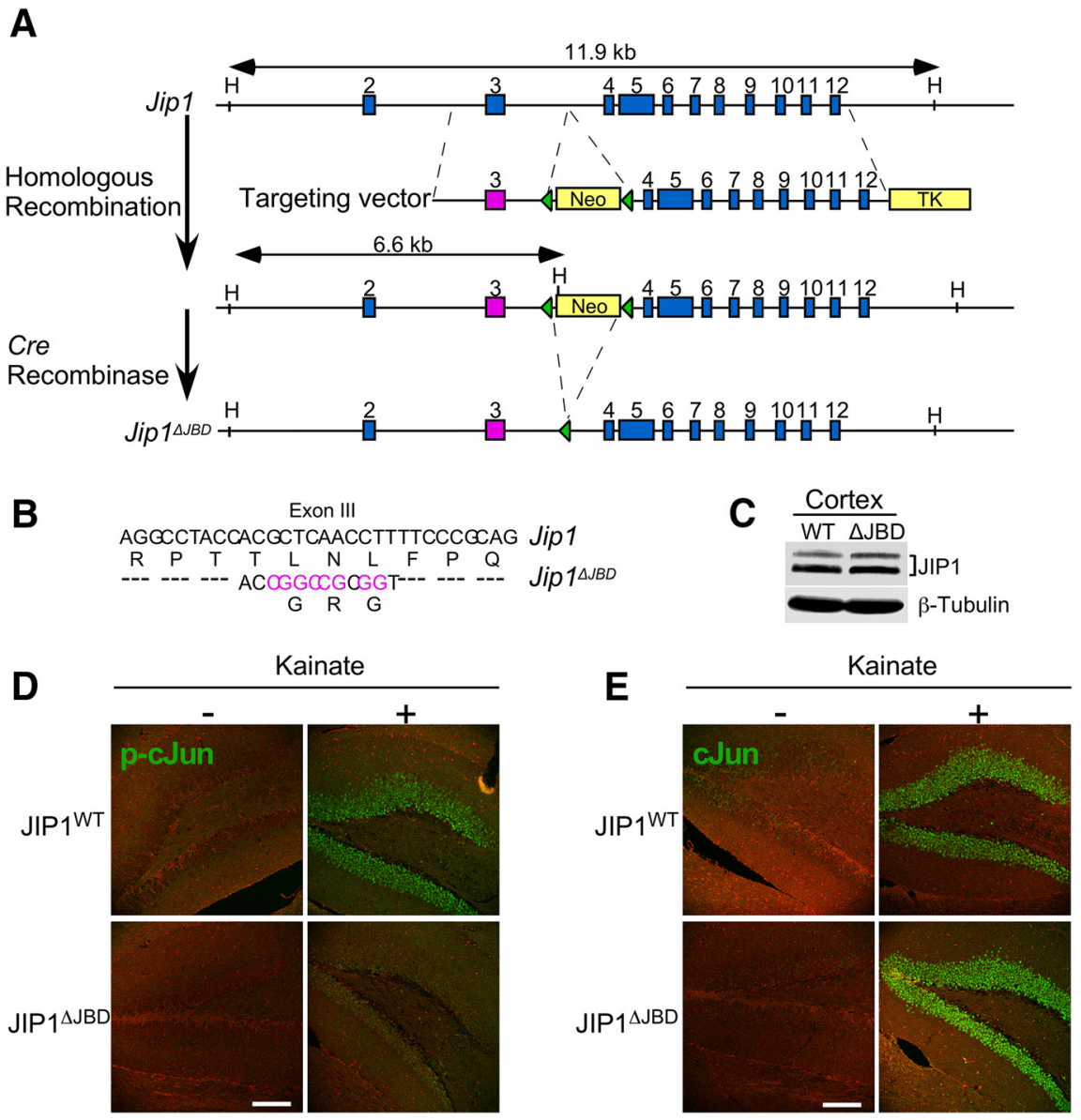

Figure 12. Suppression of kainate-induced JNK activity in the hippocampus of $J \mathrm{IP} 1^{\triangle \mathrm{JBD}}$ mice. $A, B, A$ targeting vector was recole $H$, Hindlll restriction enzyme. C, Lysates prepared from the cerebral cortex of Jip $1^{+/+}(\mathrm{WT})$ and $\mathrm{Jip} 1^{\Delta \mathrm{JBD} / \Delta \mathrm{JBD}}(\Delta \mathrm{JBD})$ mice were ed by immunoblot analysis using antibodies to JIP1 and $\beta$-Tubulin. $\mathbf{D}, \boldsymbol{E}, \mathrm{JIP}{ }^{\mathrm{WT}}$ and JIP ${ }^{\triangle \mathrm{BBD}}$ mice were treated without and with kainate. Representative sections of the DG stained (green) with antibodies to phospho-Jun (D) or cJun (E) are presented. DNA was stained with DAPI (red). Scale bar, $75 \mu \mathrm{m}$.

of the training, both JIP1 ${ }^{\mathrm{TA}}$ and JIP $1^{\mathrm{WT}}$ mice readily learned to find the marked platform (Fig. 11A). Mice were then trained to swim to a hidden platform located in a fixed location of the pool (Fig. $11 A, D$; target quadrant, T). JIP1 ${ }^{\mathrm{TA}}$ mice had significantly decreased escape latencies compared with JIP1 ${ }^{\text {WT }}$ mice on days 6-9 and day 12 of training (two-way repeated-measures ANOVA: genotype $F_{(1,208)}=11.03, p=0.0049$; time $F_{(8,208)}=21.01, p<$ 0.001 ; genotype $\times$ time $F_{(8,208)}=0.74, p=0.65$; Fig. $\left.11 A\right)$. However, JIP $1^{\text {TA }}$ and JIP1 $1^{\mathrm{WT}}$ mice did not differ in the time spent in the platform-containing quadrant during probe trials on day 10 (Fig. $11 B ; 36 \pm 3 \%$ of time in quadrant T for JIP1 ${ }^{\mathrm{TA}} ; 35 \pm 2 \%$ JIP1 ${ }^{\text {WT }} ; t_{(26)}=0.27, p=0.783$; two-tailed unpaired Student's $t$ test) and day 13 (Fig. $11 C ; 38 \pm 5 \%$ of time in quadrant $\mathrm{T}$ for $\mathrm{JIP} 1^{\mathrm{TA}}$ mice; $36 \pm 3 \% \mathrm{JIP} 1^{\mathrm{WT}}$ mice; $t_{(26)}=0.34, p=0.734$ two-tailed unpaired Student's $t$ test). Although JIP1 ${ }^{\text {TA }}$ mice did not display preference for the target quadrant during probe trials, the decrease in escape latency during training suggests that the presence of the JIP1 $\mathrm{Thr}^{103}$ Ala mutation appears to affect gradual learning of the hidden platform MWM task moderately.

To test whether JIP1 ${ }^{\mathrm{TA}}$ mice display enhanced fast spatial learning, we performed a reversal of the hidden platform in the MWM. The hidden platform was moved to the opposite quadrant of the pool (new target quadrant, NT) and the mice were 
A


C



(d9)

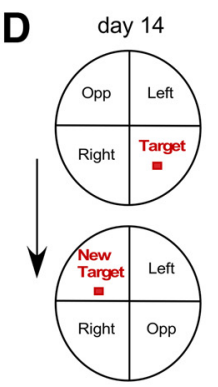

(4 trials)
B

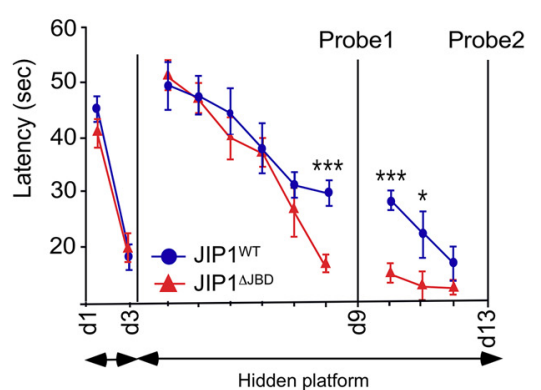

E

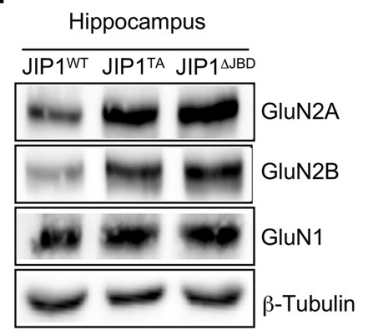

$\mathbf{F}$

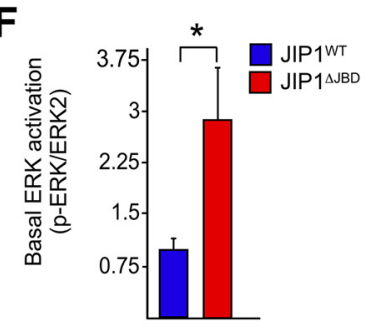

Figure 13. Disruption of the JBD $(\triangle \mathrm{J} B D)$ on JIP1 causes enhanced associative learning. $A$, Contextual and cued fear conditioning of JIP1 ${ }^{\triangle \mathrm{JBD}}$ and JIP1 ${ }^{\mathrm{WT}}$ mice consisted of one exposure to cue (context + tone) and $0.8 \mathrm{~mA}$ shock (mean $\pm \mathrm{SEM} ; n=10 \sim 11$; ${ }^{* *} p<0.01$, Student's $t$ test ${ }^{* * *} p<0.001$, Student's $t$ test). $B, C$, MWM tests of mean latencies to escape to a visible (days $1-2$ ) or a hidden platform (days 3-12) are presented for JIP1 ${ }^{\Delta \mathrm{BDO}}$ or JIP1 ${ }^{\mathrm{WT}}$ mice $(\boldsymbol{B})$. Probe trials were performed on days 9 and 13 of water maze training (C). JPP1 ${ }^{\Delta \mathrm{BBD}}$ mice spent significantly longer time in the target quadrant compared with JIP1 ${ }^{\mathrm{WT}}$ littermates (mean \pm SEM; $n=10 ;{ }^{*} p<0.05 ;{ }^{* *} p<0.01 ;{ }^{* * *} p<0.001$, two-way repeated-measures ANOVA $(\boldsymbol{B})$ and two-way ANOVA (C) followed by Bonferroni's post hoc tests). $\boldsymbol{D}$, The water maze platform was moved to the opposite quadrant in the pool and mice were trained for four trials (day 14, reversal learning). The probe test for reversal training was conducted $24 \mathrm{~h}$ after the completion of new platform training (day 15). Analysis of the time spent in the quadrants during the probe trial revealed that JIP1 ${ }^{\triangle \mathrm{JBD}}$ mice spent significantly more time in the NT than JIP1 ${ }^{\text {WT }}$ mice (mean \pm SEM; $n=10$; ${ }^{* * *} p<0.001$, two-way ANOVA followed by Bonferroni's post hoc test). $E$, Hippocampus lysates of JPP ${ }^{\mathrm{WT}}, J \mathrm{JP} 1^{\mathrm{TA}}$, and JIP1 ${ }^{\triangle \mathrm{SBD}}$ mice were examined by immunoblot analysis by probing with antibodies to NMDAR subunits and $\beta$-Tubulin. $\boldsymbol{F}$, The amount of phospho-ERK in hippocampus lysates of naive $J I P 1^{W T}$ and JIP1 ${ }^{\triangle \mathrm{SBD}}$ mice was quantified by multiplexed ELISA and normalized to the amount of ERK2 in each sample. Data are shown as mean \pm SEM. $n=5 ;{ }^{*} p<0.05$, Student's $t$ test.

trained to swim to this new location for four trials separated by 15-20 min (Fig. 11D). JIP $1^{\mathrm{TA}}$ mice learned significantly faster to swim to the new platform location compared with control mice (two-way repeated-measures ANOVA: genotype $F_{(1,78)}=16.37, p=$ 0.0012 ; time $F_{(3,78)}=1.98, p=0.13$; genotype $\times$ time $F_{(3,78)}=$ $1.86, p=0.15$; Fig. 11E). Moreover, the JIP1 ${ }^{\mathrm{TA}}$ mice displayed increased preference for the NT during a probe trial given on probe day 15 (Fig. $11 F$; time spent in NT: $41 \pm 2 \%$ for JIP1 ${ }^{\text {TA }}$; $23 \pm 4 \%$ for JIP $1{ }^{\mathrm{WT}} ; t_{(26)}=4.02, p<0.001$; two-tailed unpaired Student's $t$ test). This enhancement in spatial reversal learning of the new platform location was accompanied by a decrease in the percentage of time JIP $1^{\mathrm{TA}}$ mice spent searching for the platform in the previously correct quadrant $\left(\mathrm{O} ; t_{(26)}=2.34, p=0.028\right.$; two-tailed unpaired Student's $t$ test; Fig. 11F). These data indi-

cate that the Thr ${ }^{103}$ Ala mutation in JIP1 allows for improved fast spatial learning.

\section{JNK binding is required for JIP1-mediated NMDAR regulation of learning and memory}

To confirm that JIP1-mediated JNK activation plays a critical role in NMDAR-dependent, hippocampus-dependent learning and memory, we tested an independent mouse model of defective JIP1-mediated JNK activation: JIP1 lacking the JNK binding domain (JBD). To create a mouse model lacking the JBD of JIP1 (JIP1 $1^{\Delta \mathrm{JBD}}$ mice), the core of the JBD (Leu ${ }^{160}$. Asn ${ }^{161}$-Leu ${ }^{162}$ ) mediating a hydrophobic interaction of JIP1 with JNK (Whitmarsh et al., 2001; Heo et al., 2004) was replaced with $\mathrm{Gly}^{160}-\mathrm{Arg}^{161}-\mathrm{Gly}^{162}$ in $\mathrm{JIP}^{\Delta \mathrm{JBD}}$ mice (Fig. 12A, B). Immunoblot analysis of brain extracts from JIP1 ${ }^{\mathrm{WT}}$ and JIP1 $1^{\triangle \mathrm{JBD}}$ mice indicated similar levels of JIP1 protein expression (Fig. 12C). To establish that the $\triangle$ JBD mutation blocks JIP1mediated JNK activation in vivo, we compared kainate-induced excitotoxicity in the hippocampus of JIP1 ${ }^{\text {WT }}$ and JIP1 ${ }^{\mathrm{JBD}}$ mice. This analysis demonstrated that kainate caused similar increases in cJun expression in the DG of JIP1 ${ }^{\text {WT }}$ and JIP1 ${ }^{\Delta I B D}$ mice, but kainate-stimulated cJun phosphorylation was markedly suppressed in JIP1 ${ }^{\triangle \mathrm{JBD}}$ mice compared with JIP1 ${ }^{\mathrm{WT}}$ mice (Fig. $12 D, E$ ). These data confirm that JIP1 ${ }^{\triangle J B D}$ mice represent a model of defective JIP1-mediated JNK signaling.

We then examined contextual and cued fear conditioning to assess the effect of the JIP $1^{\triangle \mathrm{JBD}}$ mutation on learning and memory. The JIP $1^{\triangle \mathrm{JBD}}$ mice displayed a significantly increased conditioned freezing response in both learning tasks compared with the JIP $1{ }^{\text {WT }}$ mice when tested at $24 \mathrm{~h}$ after training (Fig. 13A, left: mean percentage contextual freezing; JIP $1^{\mathrm{WT}}=$ $58 \pm 3 \% ; \mathrm{JIP} 1^{\Delta \mathrm{IBD}}=89 \pm 3 \% ; t_{(18)}=6.30$, $p<0.001$; two-tailed unpaired Student's $t$ test; Fig. 13A, right: mean percentage cued freezing; JIP $1^{\mathrm{WT}}=51 \pm 1 \%$; JIP1 $1^{\Delta \mathrm{JBD}}=69 \pm 6 \% ; t_{(20)}=2.97$, $p=0.007$; two-tailed unpaired Student's $t$ test), a result very similar to that observed for the JIP1 ${ }^{\mathrm{TA}}$ mice (Fig. 10). JIP1 ${ }^{\Delta \mathrm{JBD}}$ mice exhibited enhanced learning in the MWM (two-way repeated-measures ANOVA: genotype $F_{(1,162)}=26.04, p<0.001$; time $F_{(8,162)}=126.7, p<0.001$; genotype $\times$ time ${ }_{(8,162)}=1.75$, $p=0.84$ ), and spent significantly more time in the target quadrant compared with control JIP1 ${ }^{\mathrm{WT}}$ mice when subjected to probe trials on day $9\left(t_{(18)}=4.02, p<0.001\right.$; Fig. $13 C$, left; $41 \pm$ $2 \%$ of time in quadrant $\mathrm{T}$ for JIP1 ${ }^{\triangle \mathrm{JBD}} ; 32 \pm 1 \%$ of time in

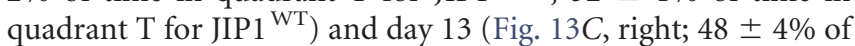
time in quadrant $\mathrm{T}$ for JIP1 ${ }^{\triangle \mathrm{JBD}} ; 36 \pm 3 \%$ of time in quadrant $\mathrm{T}$ for JIP1 $1^{\mathrm{WT}} ; t_{(18)}=2.44, p=0.027$; two-tailed unpaired Student's $t$ test). This was an unexpected finding because JIP $1^{\mathrm{TA}}$ mice did 
not show enhanced memory retention in the hidden platform MWM task (cf. Fig. $11 B, C)$. The larger phenotype in the JIP1 ${ }^{\triangle \mathrm{JBD}}$ mice in the MWM compared with the JIP $1^{\mathrm{TA}}$ mice may result from a greater effect of the JNK-binding site mutation on JIP1-mediated JNK activation than the mutation of the T103 phosphorylation site on JIP1.

We then examined reversal learning by moving the hidden platform to the opposite quadrant (Fig. 13D, left). Similar to JIP $1^{\text {TA }}$ mice, the JIP1 ${ }^{\Delta \text { JBD }}$ mice showed shorter latencies than control mice in finding the new platform location during a $1 \mathrm{~d}$ trial period (data not shown). Moreover, JIP $1^{\Delta \mathrm{JBD}}$ mice spent significantly more time in the NT compared with JIP1 ${ }^{\text {WT }}$ control mice (Fig. 13D, right; mean percentage of time spent in the NT was $49 \pm 3 \%$, for JIP1 ${ }^{\Delta \mathrm{JBD}} ; 28 \pm 4 \%$ for JIP $1^{\text {WT }} t_{(18)}=4.21, p<0.001$; two-tailed unpaired Student's $t$ test). Furthermore, like JIP $1^{\text {TA }}$ mice, we found significantly increased expression of GluN1, GluN2A, and GluN2B in the hippocampus of JIP1 ${ }^{\Delta \mathrm{JBD}}$ mice compared with hippocampi from JIP1 ${ }^{\mathrm{WT}}$ mice (Fig. 13E) and increased ERK activation $\left(t_{(8)}=2.57\right.$, $p=0.033$; two-tailed unpaired Student's $t$ test; Fig. $13 F)$.

Together, these analyses of JIP $1^{\mathrm{TA}}$ and JIP ${ }^{\triangle \mathrm{JBD}}$ mice confirm that loss of JIP1-mediated JNK activation enhances NMDAdependent hippocampus-dependent memory.

\section{Discussion}

The JIP1 scaffold protein can assemble a functional JNK signaling module formed by members of the mixed-lineage protein kinase family of MAP3K, the MAP2K family member MKK7, and JNK (Whitmarsh et al., 1998). However, JIP1 also functions as an adapter protein that mediates transport by microtubule motor proteins (Fu and Holzbaur, 2014), including kinesin-1 (Verhey et al., 2001; Whitmarsh et al., 2001) and dynein (Standen et al., 2009; Fu and Holzbaur, 2013). These two functions of JIP1 compromise the interpretation of loss-of-function studies focused on the analysis of JIP1 knock-out mice (Whitmarsh et al., 2001; Kennedy et al., 2007). To overcome this limitation, we studied two mouse models with germline mutations in the Jip1 gene that prevent JIP1-mediated JNK activation. First, a point mutation of the JIP1 phosphorylation site $\mathrm{Thr}^{103}$ (by replacement with Ala) in JIP1 ${ }^{\text {TA }}$ mice suppresses JIP1-mediated JNK activation (Fig. 3) by disrupting the regulated interaction of mixed-lineage protein kinases with JIP1 (Morel et al., 2010). Second, a three-residue mutation of the JIP1 site that binds JNK in JIP1 ${ }^{\Delta \mathrm{JBD}}$ mice prevents JIP1-mediated JNK activation (Fig. 12). These complementary mouse models therefore provided an opportunity to disrupt JIP1-mediated JNK activation selectively in vivo.

It is established that the JIP1 scaffold protein mediates JNK activation in the neuronal response to excitotoxin (Whitmarsh et al., 2001) and in adipose tissue during metabolic stress responses (Jaeschke et al., 2004; Morel et al., 2010). The results of the present study extend these findings to neural functioning by demonstrating that JIP1-linked JNK activation in the hippocampus regulates contextual fear conditioning in a NMDAR-dependent fashion. This finding builds on the previous demonstration that
JNK1-deficient mice exhibit enhanced contextual fear conditioning (Sherrin et al., 2010) and altered synaptic plasticity (Li et al., 2007).

We further show that JIP1-mediated JNK activation regulates NMDAR signal transduction associated with an altered threshold for LTP, decreased long-term fear memory, and decreased spatial memory (Figs. 5, 6, 8, 10, 11, 13). These observations are consistent with the conclusion that JNK normally functions to regulate negatively mechanisms responsible for learning and memory (Sherrin et al., 2011). We found that the enhanced learning in JIP1 mutant mice was associated with an increase in the NMDAR component of the synaptic response, and enhanced activity of downstream pathways that facilitate induction of NMDAR-dependent LTP. This is consistent with previous reports that have separately implicated both JNK signaling (Sherrin et al., 2010) and CA1 hippocampal NMDARs in contextual fear conditioning, spatial learning, and synaptic plasticity (Kutsuwada et al., 1996; Tsien et al., 1996; Tang et al., 1999; Liu et al., 2004; Lau and Zukin, 2007; Yashiro and Philpot, 2008; Brigman et al., 2010). These data indicate that JIP1-mediated JNK activation may constrain synaptic plasticity, learning, and memory through attenuation of NMDAR function. Furthermore, decreases in JIP1 level and/or localization affecting JNK activity, perhaps resulting from distinct signaling pathways (e.g., glutamate-mediated downregulation of JIP1 level in growth cones, Dajas-Bailador et al., 2014; $\mathrm{Ca}^{2+}$-dependent degradation of JIP1, AllamanPillet et al., 2003), would thus be predicted to reduce this constraint, leading to enhanced learning and memory.

The increased NMDAR signaling caused by loss of JIP1mediated JNK activation in JIP1 ${ }^{\mathrm{TA}}$ mice is associated with increased expression of the NMDAR subunits GluN2A and GluN2B (Fig. 7). This increase in the levels of NMDAR subunits is significant because it is established that changes in GluN2A and GluN2B expression cause altered plasticity and memory (Tang et al., 1999; Brigman et al., 2010; Chao et al., 2013). This may be mediated by extending the integration time window for NMDAR signaling coincident with presynaptic and postsynaptic activity and de- 
creasing the threshold for inducing long-term synaptic changes. Indeed, a constraint by JIP1-JNK on plasticity thresholds may, in turn, regulate information processing and learning (Kiyama et al., 1998; Hawasli et al., 2007; Hu et al., 2007). This is consistent with the observation that loss of JIP1-mediated JNK activation in JIP $1^{\text {TA }}$ mice enables the establishment of LTP at lower stimulation frequencies (Fig. $5 \mathrm{H}$ ), with the converse being a requirement for higher stimulation frequencies needed in the presence of JIP1-JNK activation. The mechanism of JIP1-dependent regulation of NMDAR subunit expression (Fig. $7 A, B$ ) remains to be determined and may include changes in NMDAR membrane insertion, internalization, or lateral movement into synapses (Fig. 14). In addition, JIP1 may regulate NMDAR subunit expression through a posttranscriptional mechanism (Fig. 14). Indeed, it is known that GluN1, GluN2, and GluN2B protein expression can be regulated by CPEB3 (Chao et al., 2013); that GluN2A protein expression can be regulated by CPEB1 (Udagawa et al., 2012; Swanger et al., 2013); and that GluN2B expression can be regulated by a microRNA (Harraz et al., 2012). Strikingly, the learning and memory phenotypes of $C p e b 3^{-1-}$ mice associated with increased NMDAR expression (Chao et al., 2013) are similar to the phenotypes of the mice with defects in JIP1 function examined in the present study (JIP1 ${ }^{\mathrm{TA}}$ and JIP $1^{\Delta \mathrm{JBD}}$ mice).

It is possible that increased expression of NMDAR subunits only partially accounts for the learning and memory phenotypes of JIP ${ }^{\text {TA }}$ and JIP $1^{\triangle \mathrm{JBD}}$ mice. Indeed, it has been shown that cFyn mediates phosphorylation of the NMDAR subunit GluN2B on $\mathrm{Y}^{1472}$, resulting in increased NMDAR activity (Salter and Kalia, 2004) by attenuating NMDAR internalization (Roche et al., 2001; Prybylowski et al., 2005), increasing the proper localization of the GluN2B NMDARs at synapses (Nakazawa et al., 2006), and enhancing GluN2B NMDAR-mediated currents at CA1 synapses (Yang et al., 2012). In the present study, increased GluN2B Y ${ }^{1472}$ phosphorylation resulted from disruption of JIP1-mediated JNK activation in JIP1 ${ }^{\mathrm{TA}}$ mice (Fig. $7 A$ ), also perhaps contributing to the observed increase in NMDAR signaling. This change in GluN2B Y ${ }^{1472}$ phosphorylation may be caused by JIP1-mediated recruitment of cFyn (Kennedy et al., 2007) or by JNK-mediated recruitment of PSD-95/Fyn complex (Kim et al., 2007). Another potential contributing factor may be the binding of JIP1 to LRP8, a protein that regulates NMDAR signaling (Stockinger et al., 2000; Beffert et al., 2005). Finally, it is possible that JIP1-mediated interactions with the exchange factors Ras-GRF1 and Tiam 1 may contribute to increased NMDAR-dependent activation of the ERK pathway and activity-dependent actin remodeling critical for synaptic plasticity and memory (Buchsbaum et al., 2002; Krapivinsky et al., 2003; Tolias et al., 2007).

Contextual fear learning recruits both the hippocampus and amygdala, whereas cued fear learning relies on the amygdala (Phillips and LeDoux, 1992). JIP ${ }^{\mathrm{TA}}$ and JIP1 ${ }^{\Delta \mathrm{JBD}}$ mice displayed enhancement in both contextual and cued fear conditioning (Figs. 10, 13). Therefore, these learning enhancements suggest that JIP1mediated JNK activation is also important in the amygdala. Although JIP1 is expressed in amygdala (unpublished preliminary observations), JNK signaling and the importance of JIP1 in the amygdala have yet to be investigated thoroughly. We hypothesize that the observed contextual-learning enhancement is at least in part due to a lack of hippocampal JIP1-mediated JNK signaling. Not only is signal transduction altered in this region, but JIP ${ }^{\mathrm{TA}}$ and JIP1 ${ }^{\triangle \mathrm{JBD}}$ mice also demonstrate an improved spatial water maze memory, which classically relies on the hippocampus.

Genetic anomalies within the JNK pathway have also been associated with a subset of other psychiatric disorders (Coffey,
2014). However, the degree to which and the mechanism by which JNK is involved is unknown. JIP $1{ }^{\mathrm{TA}}$ mutant mice display a range of behaviors, including exaggerated fear responses to cues associated with the danger, difficulty suppressing fear behavior even when these cues no longer predict danger, elevated acoustic startle response, and anxiety-like behaviors that may represent rodent homologs of the symptoms that are diagnostic for trauma- and stressor-related disorders, such as posttraumatic stress disorder (PTSD) (Shalev et al., 2017). These responses may be regulated by JIP1-mediated JNK signaling in the hippocampus, the amygdala, or in various cortical regions that interconnect to form the neural circuits that promote adaptation to stress and fear conditioning. Interestingly, we have shown that intrahippocampal infusion with a JNK inhibitor prevents stress-induced changes in fear conditioning (Sherrin et al., 2010). Therefore, it is possible that drugs that target the function of JIP1 to regulate JNK activity or NMDAR function positively (Myers and Davis, 2007; Feder et al., 2014; Ori et al., 2015; Mataix-Cols et al., 2017) may therefore be useful for the treatment of PTSD or anxiety disorders marked by abnormal fear learning and maladaptive processing of information related to threat. Our study provides a proof-of-concept that validates this approach using a model organism. An exciting future possibility is the application of this strategy to the treatment of human fear and anxiety.

Overall, the results of this study suggest that JNK activation caused by the JIP1 scaffold protein constrains learning and memory in an NMDAR-dependent fashion. This role of JIP1 starkly differs from the related protein JIP2 that acts to promote NMDAR signaling by a JNK-independent mechanism (Kennedy et al., 2007). Our studies of JIP1 therefore establish a role for the JIP1JNK pathway in NMDAR-dependent regulation of memory acquisition, consolidation, and retention.

\section{References}

Allaman-Pillet N, Størling J, Oberson A, Roduit R, Negri S, Sauser C, Nicod P, Beckmann JS, Schorderet DF, Mandrup-Poulsen T, Bonny C (2003) Calcium- and proteasome-dependent degradation of the JNK scaffold protein islet-brain 1. J Biol Chem 278:48720-48726. CrossRef Medline

Bading H, Ginty DD, Greenberg ME (1993) Regulation of gene expression in hippocampal neurons by distinct calcium signaling pathways. Science 260:181-186. CrossRef Medline

Baptista J, Mercer C, Prigmore E, Gribble SM, Carter NP, Maloney V, Thomas NS, Jacobs PA, Crolla JA (2008) Breakpoint mapping and array CGH in translocations: comparison of a phenotypically normal and an abnormal cohort. Am J Human Genet 82:927-936. CrossRef Medline

Beffert U, Weeber EJ, Durudas A, Qiu S, Masiulis I, Sweatt JD, Li WP, Adelmann G, Frotscher M, Hammer RE, Herz J (2005) Modulation of synaptic plasticity and memory by reelin involves differential splicing of the lipoprotein receptor Apoer2. Neuron 47:567-579. CrossRef Medline

Brigman JL, Wright T, Talani G, Prasad-Mulcare S, Jinde S, Seabold GK, Mathur P, Davis MI, Bock R, Gustin RM, Colbran RJ, Alvarez VA, Nakazawa K, Delpire E, Lovinger DM, Holmes A (2010) Loss of GluN2Bcontaining NMDA receptors in CA1 hippocampus and cortex impairs long-term depression, reduces dendritic spine density, and disrupts learning. J Neurosci 30:4590-4600. CrossRef Medline

Buchsbaum RJ, Connolly BA, Feig LA (2002) Interaction of rac exchange factors Tiam1 and ras-GRF1 with a scaffold for the p38 mitogen-activated protein kinase cascade. Mol Cell Biol 22:4073-4085. CrossRef Medline

Chao HW, Tsai LY, Lu YL, Lin PY, Huang WH, Chou HJ, Lu WH, Lin HC, Lee PT, Huang YS (2013) Deletion of CPEB3 enhances hippocampusdependent memory via increasing expressions of PSD95 and NMDA receptors. J Neurosci 33:17008-17022. CrossRef Medline

Chen JT, Lu DH, Chia CP, Ruan DY, Sabapathy K, Xiao ZC (2005) Impaired long-term potentiation in c-jun $\mathrm{N}$-terminal kinase 2-deficient mice. J Neurochem 93:463-473. CrossRef Medline 
Citri A, Malenka RC (2008) Synaptic plasticity: multiple forms, functions, and mechanisms. Neuropsychopharmacology 33:18-41. CrossRef Medline

Coffey ET (2014) Nuclear and cytosolic JNK signalling in neurons. Nat Rev Neurosci 15:285-299. CrossRef Medline

Collingridge GL, Peineau S, Howland JG, Wang YT (2010) Long-term depression in the CNS. Nat Rev Neurosci 11:459-473. CrossRef Medline

Curran BP, Murray HJ, O'Connor JJ (2003) A role for c-jun N-terminal kinase in the inhibition of long-term potentiation by interleukin-1beta and long-term depression in the rat dentate gyrus in vitro. Neuroscience 118:347-357. CrossRef Medline

Dajas-Bailador F, Bantounas I, Jones EV, Whitmarsh AJ (2014) Regulation of axon growth by the JIP1-AKT axis. J Cell Sci 127:230-239. CrossRef Medline

Davis RJ (2000) Signal transduction by the JNK group of MAP kinases. Cell 103:239-252. CrossRef Medline

de Anda FC, Rosario AL, Durak O, Tran T, Gräff J, Meletis K, Rei D, Soda T, Madabhushi R, Ginty DD, Kolodkin AL, Tsai LH (2012) Autism spectrum disorder susceptibility gene TAOK2 affects basal dendrite formation in the neocortex. Nat Neurosci 15:1022-1031. CrossRef Medline

Dickens M, Rogers JS, Cavanagh J, Raitano A, Xia Z, Halpern JR, Greenberg ME, Sawyers CL, Davis RJ (1997) A cytoplasmic inhibitor of the JNK signal transduction pathway. Science 277:693-696. CrossRef Medline

Dudek SM, Bear MF (1992) Homosynaptic long-term depression in area CA1 of hippocampus and effects of N-methyl-D-aspartate receptor blockade. Proc Natl Acad Sci U S A 89:4363-4367. CrossRef Medline

Feder A, Parides MK, Murrough JW, Perez AM, Morgan JE, Saxena S, Kirkwood K, Aan Het Rot M, Lapidus KA, Wan LB, Iosifescu D, Charney DS (2014) Efficacy of intravenous ketamine for treatment of chronic posttraumatic stress disorder: a randomized clinical trial. JAMA Psychiatry 71:681-688. CrossRef Medline

Fu MM, Holzbaur EL (2013) JIP1 regulates the directionality of APP axonal transport by coordinating kinesin and dynein motors. J Cell Biol 202:495508. CrossRef Medline

Fu MM, Holzbaur EL (2014) Integrated regulation of motor-driven organelle transport by scaffolding proteins. Trends Cell Biol 24:564-574. CrossRef Medline

Ghosh A, Carnahan J, Greenberg ME (1994) Requirement for BDNF in activity-dependent survival of cortical neurons. Science 263:1618-1623. CrossRef Medline

Ginty DD, Kornhauser JM, Thompson MA, Bading H, Mayo KE, Takahashi JS, Greenberg ME (1993) Regulation of CREB phosphorylation in the suprachiasmatic nucleus by light and a circadian clock. Science 260:238241. CrossRef Medline

Giza J, Urbanski MJ, Prestori F, Bandyopadhyay B, Yam A, Friedrich V, Kelley K, D’Angelo E, Goldfarb M (2010) Behavioral and cerebellar transmission deficits in mice lacking the autism-linked gene islet brain-2. J Neurosci 30:14805-14816. CrossRef Medline

Grillon C, Morgan CA 3rd, Davis M, Southwick SM (1998) Effects of experimental context and explicit threat cues on acoustic startle in Vietnam veterans with posttraumatic stress disorder. Biol Psychiat 44:1027-1036. CrossRef Medline

Harraz MM, Eacker SM, Wang X, Dawson TM, Dawson VL (2012) MicroRNA-223 is neuroprotective by targeting glutamate receptors. Proc Natl Acad Sci U S A 109:18962-18967. CrossRef Medline

Hawasli AH, Benavides DR, Nguyen C, Kansy JW, Hayashi K, Chambon P, Greengard P, Powell CM, Cooper DC, Bibb JA (2007) Cyclin-dependent kinase 5 governs learning and synaptic plasticity via control of NMDA receptor degradation. Nat Neurosci 10:880-886. CrossRef Medline

Heo YS, Kim SK, Seo CI, Kim YK, Sung BJ, Lee HS, Lee JI, Park SY, Kim JH, Hwang KY, Hyun YL, Jeon YH, Ro S, Cho JM, Lee TG, Yang CH (2004) Structural basis for the selective inhibition of JNK1 by the scaffolding protein JIP1 and SP600125. EMBO J 23:2185-2195. CrossRef Medline

Hu H, Real E, Takamiya K, Kang MG, Ledoux J, Huganir RL, Malinow R (2007) Emotion enhances learning via norepinephrine regulation of AMPA-receptor trafficking. Cell 131:160-173. CrossRef Medline

Huber KM, Roder JC, Bear MF (2001) Chemical induction of mGluR5- and protein synthesis-dependent long-term depression in hippocampal area CA1. J Neurophysiol 86:321-325. CrossRef Medline

Igaz LM, Vianna MR, Medina JH, Izquierdo I (2002) Two time periods of hippocampal mRNA synthesis are required for memory consolidation of fear-motivated learning. J Neurosci 22:6781-6789. Medline
Inoue A, Sawatari E, Hisamoto N, Kitazono T, Teramoto T, Fujiwara M, Matsumoto K, Ishihara T (2013) Forgetting in C. elegans is accelerated by neuronal communication via the TIR-1/JNK-1 pathway. Cell Rep 3:808-819. CrossRef Medline

Jaeschke A, Czech MP, Davis RJ (2004) An essential role of the JIP1 scaffold protein for JNK activation in adipose tissue. Genes Dev 18:1976-1980. CrossRef Medline

Kant S, Standen CL, Morel C, Jung DY, Kim JK, Swat W, Flavell RA, Davis RJ (2017) A protein scaffold coordinates SRC-mediated JNK activation in response to metabolic stress. Cell Rep 20:2775-2783. CrossRef Medline

Kennedy NJ, Martin G, Ehrhardt AG, Cavanagh-Kyros J, Kuan CY, Rakic P, Flavell RA, Treistman SN, Davis RJ (2007) Requirement of JIP scaffold proteins for NMDA-mediated signal transduction. Genes Dev 21:23362346. CrossRef Medline

Kim MJ, Futai K, Jo J, Hayashi Y, Cho K, Sheng M (2007) Synaptic accumulation of PSD-95 and synaptic function regulated by phosphorylation of serine-295 of PSD-95. Neuron 56:488 -502. CrossRef Medline

Kiyama Y, Manabe T, Sakimura K, Kawakami F, Mori H, Mishina M (1998) Increased thresholds for long-term potentiation and contextual learning in mice lacking the NMDA-type glutamate receptor epsilon 1 subunit. J Neurosci 18:6704-6712. Medline

Korobova F, Svitkina T (2010) Molecular architecture of synaptic actin cytoskeleton in hippocampal neurons reveals a mechanism of dendritic spine morphogenesis. Mol Biol Cell 21:165-176. CrossRef Medline

Krapivinsky G, Krapivinsky L, Manasian Y, Ivanov A, Tyzio R, Pellegrino C, Ben-Ari Y, Clapham DE, Medina I (2003) The NMDA receptor is coupled to the ERK pathway by a direct interaction between NR2B and RasGRF1. Neuron 40:775-784. CrossRef Medline

Kunde SA, Rademacher N, Tzschach A, Wiedersberg E, Ullmann R, Kalscheuer VM, Shoichet SA (2013) Characterisation of de novo MAPK10/JNK3 truncation mutations associated with cognitive disorders in two unrelated patients. Hum Genet 132:461-471. CrossRef Medline

Kutsuwada T, Sakimura K, Manabe T, Takayama C, Katakura N, Kushiya E, Natsume R, Watanabe M, Inoue $\mathrm{Y}$, Yagi T, Aizawa S, Arakawa M, Takahashi T, Nakamura Y, Mori H, Mishina M (1996) Impairment of suckling response, trigeminal neuronal pattern formation, and hippocampal LTD in NMDA receptor epsilon 2 subunit mutant mice. Neuron 16:333344. CrossRef Medline

Lau CG, Zukin RS (2007) NMDA receptor trafficking in synaptic plasticity and neuropsychiatric disorders. Nat Rev Neurosci 8:413-426. CrossRef Medline

Lawrence JL, Tong M, Alfulaij N, Sherrin T, Contarino M, White MM, Bellinger FP, Todorovic C, Nichols RA (2014) Regulation of presynaptic Ca2+, synaptic plasticity and contextual fear conditioning by a $\mathrm{N}$-terminal betaamyloid fragment. J Neurosci 34:14210-14218. CrossRef Medline

Leaderbrand K, Corcoran KA, Radulovic J (2014) Co-activation of NR2A and NR2B subunits induces resistance to fear extinction. Neurobiol Learn Mem 113:35-40. CrossRef Medline

Liao D, Hessler NA, Malinow R (1995) Activation of postsynaptically silent synapses during pairing-induced LTP in CA1 region of hippocampal slice. Nature 375:400-404. CrossRef Medline

Li XM, Li CC, Yu SS, Chen JT, Sabapathy K, Ruan DY (2007) JNK1 contributes to metabotropic glutamate receptor-dependent long-term depression and short-term synaptic plasticity in the mice area hippocampal CA1. Eur J Neurosci 25:391-396. CrossRef Medline

Liu L, Wong TP, Pozza MF, Lingenhoehl K, Wang Y, Sheng M, Auberson YP, Wang YT (2004) Role of NMDA receptor subtypes in governing the direction of hippocampal synaptic plasticity. Science 304:1021-1024. CrossRef Medline

Mataix-Cols D, Fernández de la Cruz L, Monzani B, Rosenfield D, Andersson E, Pérez-Vigil A, Frumento P, de Kleine RA, Difede J, Dunlop BW, Farrell LJ, Geller D, Gerardi M, Guastella AJ, Hofmann SG, Hendriks GJ, Kushner MG, Lee FS, Lenze EJ, Levinson CA, et al. (2017) D-cycloserine augmentation of exposure-based cognitive behavior therapy for anxiety, obsessive-compulsive, and posttraumatic stress disorders: a systematic review and meta-analysis of individual participant data. JAMA Psychiatry 74:501-510. CrossRef Medline

Morel C, Standen CL, Jung DY, Gray S, Ong H, Flavell RA, Kim JK, Davis RJ (2010) Requirement of JIP1-mediated c-jun N-terminal kinase activation for obesity-induced insulin resistance. Mol Cell Biol 30:4616-4625. CrossRef Medline 
Morris RG, Garrud P, Rawlins JN, O’Keefe J (1982) Place navigation impaired in rats with hippocampal lesions. Nature 297:681-683. CrossRef Medline

Morrison DK, Davis RJ (2003) Regulation of MAP kinase signaling modules by scaffold proteins in mammals. Annu Rev Cell Dev Biol 19:91-118. CrossRef Medline

Mukherjee PK, DeCoster MA, Campbell FZ, Davis RJ, Bazan NG (1999) Glutamate receptor signaling interplay modulates stress-sensitive mitogen-activated protein kinases and neuronal cell death. J Biol Chem 274:6493-6498. CrossRef Medline

Myers KM, Davis M (2007) Mechanisms of fear extinction. Mol Psychiatry 12:120-150. CrossRef Medline

Myme CI, Sugino K, Turrigiano GG, Nelson SB (2003) The NMDA-toAMPA ratio at synapses onto layer $2 / 3$ pyramidal neurons is conserved across prefrontal and visual cortices. J Neurophysiol 90:771-779. CrossRef Medline

Nakano M, Yamada S, Udagawa R, Kato N (2004) Frequency-dependent requirement for calcium store-operated mechanisms in induction of homosynaptic long-term depression at hippocampus CA1 synapses. Eur J Neurosci 19:2881-2887. CrossRef Medline

Nakazawa T, Komai S, Watabe AM, Kiyama Y, Fukaya M, Arima-Yoshida F, Horai R, Sudo K, Ebine K, Delawary M, Goto J, Umemori H, Tezuka T, Iwakura Y, Watanabe M, Yamamoto T, Manabe T (2006) NR2B tyrosine phosphorylation modulates fear learning as well as amygdaloid synaptic plasticity. EMBO J 25:2867-2877. CrossRef Medline

Nihalani D, Wong HN, Holzman LB (2003) Recruitment of JNK to JIP1 and JNK-dependent JIP1 phosphorylation regulates JNK module dynamics and activation. J Biol Chem 278:28694-28702. CrossRef Medline

Ori R, Amos T, Bergman H, Soares-Weiser K, Ipser JC, Stein DJ (2015) Augmentation of cognitive and behavioural therapies (CBT) with d-cycloserine for anxiety and related disorders. Cochrane Database Syst Rev 5:CD007803. CrossRef Medline

Pellet JB, Haefliger JA, Staple JK, Widmann C, Welker E, Hirling H, Bonny C, Nicod P, Catsicas S, Waeber G, Riederer BM (2000) Spatial, temporal and subcellular localization of islet-brain 1 (IB1), a homologue of JIP-1, in mouse brain. Eur J Neurosci 12:621-632. CrossRef Medline

Phillips RG, LeDoux JE (1992) Differential contribution of amygdala and hippocampus to cued and contextual fear conditioning. Behav Neurosci 106:274-285. CrossRef Medline

Pitts MW, Raman AV, Hashimoto AC, Todorovic C, Nichols RA, Berry MJ (2012) Deletion of selenoprotein P results in impaired function of parvalbumin interneurons and alterations in fear learning and sensorimotor gating. Neuroscience 208:58-68. CrossRef Medline

Prybylowski K, Chang K, Sans N, Kan L, Vicini S, Wenthold RJ (2005) The synaptic localization of NR2B-containing NMDA receptors is controlled by interactions with PDZ proteins and AP-2. Neuron 47:845-857. CrossRef Medline

Roche KW, Standley S, McCallum J, Dune Ly C, Ehlers MD, Wenthold RJ (2001) Molecular determinants of NMDA receptor internalization. Nat Neurosci 4:794-802. CrossRef Medline

Salter MW, Kalia LV (2004) SRC kinases: a hub for NMDA receptor regulation. Rev Neurosci 5:317-328. CrossRef Medline

Santini E, Muller RU, Quirk GJ (2001) Consolidation of extinction learning involves transfer from NMDA-independent to NMDA-dependent memory. J Neurosci 21:9009-9017. Medline

Shalev A, Liberzon I, Marmar C (2017) Post-traumatic stress disorder. N Engl J Med 376:2459-2469. CrossRef Medline

Shalin SC, Hernandez CM, Dougherty MK, Morrison DK, Sweatt JD (2006) Kinase suppressor of Ras1 compartmentalizes hippocampal signal transduction and subserves synaptic plasticity and memory formation. Neuron 50:765-779. CrossRef Medline

Sherrin T, Blank T, Hippel C, Rayner M, Davis RJ, Todorovic C (2010) Hippocampal c-jun-N-terminal kinases serve as negative regulators of associative learning. J Neurosci 30:13348-13361. CrossRef Medline

Sherrin T, Blank T, Todorovic C (2011) c-jun N-terminal kinases in memory and synaptic plasticity. Rev Neurosci 22:403-410. CrossRef Medline

Shoichet SA, Duprez L, Hagens O, Waetzig V, Menzel C, Herdegen T, Schweiger S, Dan B, Vamos E, Ropers HH, Kalscheuer VM (2006) Truncation of the CNS-expressed JNK3 in a patient with a severe developmental epileptic encephalopathy. Hum Genet 118:559-567. CrossRef Medline

Sotres-Bayon F, Bush DE, LeDoux JE (2007) Acquisition of fear extinction requires activation of NR2B-containing NMDA receptors in the lateral amygdala. Neuropsychopharmacology 32:1929-1940. CrossRef Medline

Standen CL, Kennedy NJ, Flavell RA, Davis RJ (2009) Signal transduction cross talk mediated by jun $\mathrm{N}$-terminal kinase-interacting protein and insulin receptor substrate scaffold protein complexes. Mol Cell Biol 29: 4831-4840. CrossRef Medline

Stockinger W, Brandes C, Fasching D, Hermann M, Gotthardt M, Herz J, Schneider WJ, Nimpf J (2000) The reelin receptor ApoER2 recruits JNKinteracting proteins-1 and -2. J Biol Chem 275:25625-25632. CrossRef Medline

Suzuki A, Josselyn SA, Frankland PW, Masushige S, Silva AJ, Kida S (2004) Memory reconsolidation and extinction have distinct temporal and biochemical signatures. J Neurosci 24:4787-4795. CrossRef Medline

Swanger SA, He YA, Richter JD, Bassell GJ (2013) Dendritic GluN2A synthesis mediates activity-induced NMDA receptor insertion. J Neurosci 33:8898-8908. CrossRef Medline

Szapiro G, Vianna MR, McGaugh JL, Medina JH, Izquierdo I (2003) The role of NMDA glutamate receptors, PKA, MAPK, and CAMKII in the hippocampus in extinction of conditioned fear. Hippocampus 13:53-58. CrossRef Medline

Tabuchi A, Nakaoka R, Amano K, Yukimine M, Andoh T, Kuraishi Y, Tsuda M (2000) Differential activation of brain-derived neurotrophic factor gene promoters I and III by Ca2+ signals evoked via L-type voltagedependent and N-methyl-D-aspartate receptor Ca2+ channels. J Biol Chem 275:17269-17275. CrossRef Medline

Tang YP, Shimizu E, Dube GR, Rampon C, Kerchner GA, Zhuo M, Liu G, Tsien JZ (1999) Genetic enhancement of learning and memory in mice. Nature 401:63-69. CrossRef Medline

Todorovic C, Radulovic J, Jahn O, Radulovic M, Sherrin T, Hippel C, Spiess J (2007) Differential activation of CRF receptor subtypes removes stressinduced memory deficit and anxiety. Eur J Neurosci 25:3385-3397. CrossRef Medline

Tolias KF, Bikoff JB, Kane CG, Tolias CS, Hu L, Greenberg ME (2007) The Rac1 guanine nucleotide exchange factor Tiam1 mediates EphB receptordependent dendritic spine development. Proc Natl Acad Sci U S A 104: 7265-7270. CrossRef Medline

Tsien JZ, Huerta PT, Tonegawa S (1996) The essential role of hippocampal CA1 NMDA receptor-dependent synaptic plasticity in spatial memory. Cell 87:1327-1338. CrossRef Medline

Udagawa T, Swanger SA, Takeuchi K, Kim JH, Nalavadi V, Shin J, Lorenz LJ, Zukin RS, Bassell GJ, Richter JD (2012) Bidirectional control of mRNA translation and synaptic plasticity by the cytoplasmic polyadenylation complex. Mol Cell 47:253-266. CrossRef Medline

Verhey KJ, Meyer D, Deehan R, Blenis J, Schnapp BJ, Rapoport TA, Margolis B (2001) Cargo of kinesin identified as JIP scaffolding proteins and associated signaling molecules. J Cell Biol 152:959-970. CrossRef Medline

Villasana LE, Klann E, Tejada-Simon MV (2006) Rapid isolation of synaptoneurosomes and postsynaptic densities from adult mouse hippocampus. J Neurosci Methods 158:30-36. CrossRef Medline

Wang Q, Walsh DM, Rowan MJ, Selkoe DJ, Anwyl R (2004) Block of longterm potentiation by naturally secreted and synthetic amyloid betapeptide in hippocampal slices is mediated via activation of the kinases c-jun $\mathrm{N}$-terminal kinase, cyclin-dependent kinase 5, and p38 mitogenactivated protein kinase as well as metabotropic glutamate receptor type 5. J Neurosci 24:3370-3378. CrossRef Medline

Weiss LA, Shen Y, Korn JM, Arking DE, Miller DT, Fossdal R, Saemundsen E, Stefansson H, Ferreira MA, Green T, Platt OS, Ruderfer DM, Walsh CA, Altshuler D, Chakravarti A, Tanzi RE, Stefansson K, Santangelo SL, Gusella JF, Sklar P, et al. (2008) Association between microdeletion and microduplication at 16p11.2 and autism. N Engl J Med 358:667-675. CrossRef Medline

Whitmarsh AJ, Cavanagh J, Tournier C, Yasuda J, Davis RJ (1998) Mammalian scaffold complex that selectively mediates MAP kinase activation. Science 281:1671-1674. CrossRef Medline

Whitmarsh AJ, Kuan CY, Kennedy NJ, Kelkar N, Haydar TF, Mordes JP, Appel M, Rossini AA, Jones SN, Flavell RA, Rakic P, Davis RJ (2001) Requirement of the JIP1 scaffold protein for stress-induced JNK activation. Genes Dev 15:2421-2432. CrossRef Medline

Winchester CL, Ohzeki H, Vouyiouklis DA, Thompson R, Penninger JM, Yamagami K, Norrie JD, Hunter R, Pratt JA, Morris BJ (2012) Converg- 
ing evidence that sequence variations in the novel candidate gene MAP2K7 (MKK7) are functionally associated with schizophrenia. Hum Mol Genet 21:4910-4921. CrossRef Medline

Xia Z, Dudek H, Miranti CK, Greenberg ME (1996) Calcium influx via the NMDA receptor induces immediate early gene transcription by a MAP kinase/ERK-dependent mechanism. J Neurosci 16:5425-5436. Medline

Yang DD, Kuan CY, Whitmarsh AJ, Rincón M, Zheng TS, Davis RJ, Rakic P, Flavell RA (1997) Absence of excitotoxicity-induced apoptosis in the hippocampus of mice lacking the Jnk3 gene. Nature 389:865-870. CrossRef Medline

Yang H, Courtney MJ, Martinsson P, Manahan-Vaughan D (2011) Hippocampal long-term depression is enhanced, depotentiation is inhibited and long-term potentiation is unaffected by the application of a selective c-jun N-terminal kinase inhibitor to freely behaving rats. Eur J Neurosci 33:1647-1655. CrossRef Medline

Yang K, Trepanier C, Sidhu B, Xie YF, Li H, Lei G, Salter MW, Orser BA, Nakazawa T, Yamamoto T, Jackson MF, Macdonald JF (2012) Meta- plasticity gated through differential regulation of GluN2A versus GluN2B receptors by src family kinases. EMBO J 31:805-816. CrossRef Medline

Yashiro K, Philpot BD (2008) Regulation of NMDA receptor subunit expression and its implications for LTD, LTP, and metaplasticity. Neuropharmacology 55:1081-1094. CrossRef Medline

Yin X, Takei Y, Kido MA, Hirokawa N (2011) Molecular motor KIF17 is fundamental for memory and learning via differential support of synaptic NR2A/2B levels. Neuron 70:310-325. CrossRef Medline

Yin X, Feng X, Takei Y, Hirokawa N (2012) Regulation of NMDA receptor transport: a KIF17-cargo binding/releasing underlies synaptic plasticity and memory in vivo. J Neurosci 32:5486-5499. CrossRef Medline

Zhu Y, Pak D, Qin Y, McCormack SG, Kim MJ, Baumgart JP, Velamoor V, Auberson YP, Osten P, van Aelst L, Sheng M, Zhu JJ (2005) Rap2-JNK removes synaptic AMPA receptors during depotentiation. Neuron 46: 905-916. CrossRef Medline

Zucker RS, Regehr WG (2002) Short-term synaptic plasticity. Annu Rev Physiol 64:355-405. CrossRef Medline 